Archives of Agriculture and Environmental Science

\title{
Chronic exposure assessment of toxic elements from agricultural soils around the industrial areas of Tangail district, Bangladesh
}

\author{
Ram Proshad ${ }^{1^{*}}$ (D) , Tapos Kormoker ${ }^{2}$ (D) , Md. Saiful Islam ${ }^{1,3}$, Md. Abu Hanif ${ }^{4,5}$ and Krishno Chandra ${ }^{6}$ \\ ${ }^{1}$ Department of Soil Science, Patuakhali Science and Technology University, Dumki, Patuakhali-8602, BANGLADESH \\ ${ }^{2}$ Department of Emergency Management, Patuakhali Science and Technology University, Dumki, Patuakhali-8602, BANGLADESH \\ ${ }^{3}$ Laboratory of Plant Nutrition and Fertilizers, Graduate School of Agricultural and Life Sciences, The University of Tokyo, JAPAN \\ ${ }^{4}$ Department of Agroforestry and Environment, Hajee Mohammad Danesh Science and Technology University, Dinajpur, \\ BANGLADESH \\ ${ }^{5}$ Key Laboratory of Vegetation Restoration and Management of Degraded Ecosystems South China Botanical Garden, Chinese \\ Academy of Sciences (CAS), Guangzhou, CHINA \\ ${ }^{6}$ Department of Chemistry, Government Saadat College, Karatia, Tangail, BANGLADESH \\ "Corresponding author's E-mail: ramproshadpstu03470@gmail.com
}

\section{ARTICLE HISTORY}

Received: 18 November 2018

Revised received: 26 November 2018

Accepted: 30 November 2018

\section{Keywords}

Bangladesh

Carcinogenic risk

Chronic daily intake

Ecological risk

Health risk

Toxic elements

\begin{abstract}
The present research was conducted to evaluate the potential ecological and human health risk of toxic elements $(\mathrm{Cr}, \mathrm{Ni}, \mathrm{Cu}, \mathrm{As}, \mathrm{Cd}$ and $\mathrm{Pb}$ ) from agricultural soils around the industrial areas of Tangail district in Bangladesh. Potential ecological and human health risk were assessed through enrichment factor (EF), contamination factor $\left(\mathrm{C}_{\mathrm{f}}^{\mathrm{i}}\right)$, geoaccumulation index $\left(\mathrm{I}_{\text {geo }}\right)$, pollution load index (PLI), toxic unit analysis, exposure pathway, hazard quotient and hazard index. The mean concentration of $\mathrm{Cr}, \mathrm{Ni}, \mathrm{Cu}, \mathrm{As}, \mathrm{Cd}$ and $\mathrm{Pb}$ in the studied soils were $5.88,13.92,18.07,5.90,2.19$ and $8.08 \mathrm{mg} / \mathrm{kg}$, respectively. The mean values of enrichment factor, geoaccumulation index, contamination factor, pollution load index and toxic units were found low for all metals excluding $\mathrm{Cd}$. Considering the severity of potential ecological risk factor for single metal $\left(E_{r}^{i}\right)$, the descending order of pollutants was $\mathrm{Cd}>\mathrm{As}>\mathrm{Cu}>\mathrm{Ni}>\mathrm{Pb}>$ $\mathrm{Cr}$. In the perspective of potential ecological risk (PER), soils from all sampling sites indicated moderate to very high PER. Chronic daily intake values were higher in children than the adult for both ingestion and dermal contact as body weight of children was lower than the adult. The non-cancer health risks related to individual element exposure through soil ingestion, dermal contact and inhalation was low for all investigated elements resulted in a $\mathrm{HQ}<1$, indicating low risk for both adults and children. Considering the total exposure of hazard index of ingestion, dermal contact and inhalation, there was no chance of having non-cancer risk for the inhabitants of the studied industrial area. Carcinogenic risks for both adult and children lying between an acceptable ranges.
\end{abstract}

(C)2018 Agriculture and Environmental Science Academy

Citation to this article: Proshad, R., Kormoker, T., Islam, S.M., Hanif, M.A. and Chandra, K. (2018). Chronic exposure assessment of toxic elements from agricultural soils around the industrial areas of Tangail district, Bangladesh. Archives of Agriculture and Environmental Science, 3(4): 317-336, https://dx.doi.org/10.26832/24566632.2018.030401

\section{INTRODUCTION}

Soil contamination by toxic elements is considered as the most adverse environmental issue in the world (Islam et al., 2015a, 2018; Proshad et al., 2017a). Soil is a vital component for human life to survive on the earth which is anticipated as principal receiver of persistent pollutants such as toxic trace elements
(Luo et al., 2007; Karim et al., 2014; Islam et al., 2015b). Heavy metal pollutions in soils are of great concern due to their wide sources, toxicity, non-biodegradable nature and toxicity to human and other organisms (Yuan et al., 2011; Zhao et al., 2014; Islam et al., 2015a, 2018; Bhuyan and Bakar, 2017; Bhuyan et al., 2017). In the last few decades, there has been a significant concern regarding soil contamination by various trace elements 
due to rapid industrialization and development, especially in developing countries like Bangladesh (Khan et al., 2008; Chen et al., 2010; Sun et al., 2010; Islam et al., 2015a, 2018). In the industrial areas, trace elements may originate in soils from numerous activities such as emissions from vehicular exhaust, generation of power, manufacturing, burning of fossil fuel, wastewater irrigation and disposal of waste (Rodríguez et al., 2014; Islam et al., 2016, Proshad et al., 2018a). Hazardous elements toxicity changes surface soil physical, chemical, and biological features that have a significant negative consequence on the productivity of land (Khan et al., 2010).

The contaminations of heavy metals in soil have exerted longterm ecological and health effects (Needleman, 1980; Mclaughlin et al., 1999). Crops which are being cultivated in the contaminated agricultural soils may cause serious carcinogenic and non-carcinogenic risks to the human body (Man et al., 2010; Proshad et al., 2018b). Heavy metals (chromium, copper, cadmium and lead) and metalloid (arsenic) are of particular concern because of very well-known detrimental health effects on humans in excessive quantities (Shaheen et al., 2016, Islam et al., 2018). In the industrial areas, heavy metal polluted soil can pose significant human health risks due to soil ingestion, inhalation of volatiles and fugitive soil particulates, and dermal contact, especially in the public parks and playgrounds (Siciliano et al., 2009; Luo et al., 2011; Okorie et al., 2011; Li et al., 2011). Therefore, exposure to heavy metal pollutants is of utmost concern for children in their primary developmental years and also for the adult (Lee et al., 2013; Rachwał et al., 2017). However, research on possible health risk due to heavy metals pollution in soil of the industrial area is very essential. Tangail district is an industrialized area of Bangladesh that is supposed to be highly contaminated by heavy metals. This area is well-known for agricultural production and it provides a large portion of agricultural products all over the country (Huq and Shoaib, 2013). Although several studies have conducted for assessing human health risk due to heavy metal contamination from soil in the urban and industrial regions of the world (Chen et al., 2005, Luo et al., 2007, Man et al., 2010, Proshad et al., 2017b), but there is very limited research has been conducted so far on heavy metals in soil and its adverse effects on the environment as well as human health especially the industrial area like Tangail district. Therefore, the present research was conducted to address the following questions: i) what are the concentration of heavy metals in soils of the studied industrial area? ii) Is the concentration of heavy metals is alarming for our environment? iii) Is it possesses potential health risk?

\section{MATERIALS AND METHODS}

\section{Study area and sampling}

This study was conducted in Bangladesh Small and Cottage Industries Corporation (BSCIC) areas of Tangail district, Bangladesh (Figure 1). It is one of the densely populated (1,100/square $\mathrm{Km}$ ) district of the country having an area of $334.26 \mathrm{Km}^{2}$. Tangail Sadar Upazila is one of the most densely polluted area in
Bangladesh where the density of population is $1,100 / \mathrm{Km}^{2}$ (2011 census) (BBS, 2011). The study area is situated between at $24.20^{\circ} \mathrm{N}$ to $89.58^{\circ} \mathrm{E}$. Tangail is an industrial growing site of Bangladesh, which is highly susceptible to environmental pollution over the last decade (Proshad et al., 2018c). There are several types of industrial units including garments, tannery industries packaging industry, dyeing, brick kiln, metal workshops, battery manufacturing industries, tanneries, textile industries, pesticide and fertilizer industries, different food processing industries and other factories of $\mathrm{BSCIC}$ industrial areas produce huge volumes of effluents that contain trace metals. The untreated wastes and effluents from these industries are discharged randomly to river and canals. Then that wastes are mixed with soils and the soil is continuously polluted by heavy metals.

Soil samples were collected during March-April, 2016. Ten agricultural soil sampling locations were selected in the industrial areas of Tangail district. Agricultural soil samples (up to 10 $\mathrm{cm}$ ) were collected in the form of three subsamples. These sub-samples were thoroughly mixed to form a composite sample. Samples were air-dried at room temperature for two weeks, then ground and homogenized. The dried soil samples were crumbled with a porcelain mortar and pestle and sieved through $2 \mathrm{~mm}$ nylon sieve and stored in an airtight clean Ziploc bag and kept frozen until chemical analysis (Oliveira et al., 2012; Arenas-Lago et al., 2013, 2014).

\section{Physicochemical parameters analysis}

Soil $\mathrm{pH}$ was determined by using a glass electrode $\mathrm{pH}$ meter (WTW pH 522; Germany). $10 \mathrm{~g}$ of air-dried soil from each sampling site was taken in $50 \mathrm{~mL}$ beakers separately and $25 \mathrm{~mL}$ of distilled water was added to each beaker. The suspension was stirred well for 20 minutes and allowed to stand for about 30 minutes. Then each sample was stirred again for 2 minutes before taking the reading. The position of the electrode was immersed into the partly settled soil suspension and $\mathrm{pH}$ was measured. For EC determination, $5.0 \mathrm{~g}$ of soil was taken in $50 \mathrm{~mL}$ polypropylene tubes and $30 \mathrm{~mL}$ of Milli-Q water was added to the tube. The lid was closed properly and was shaken for $5 \mathrm{~min}$.

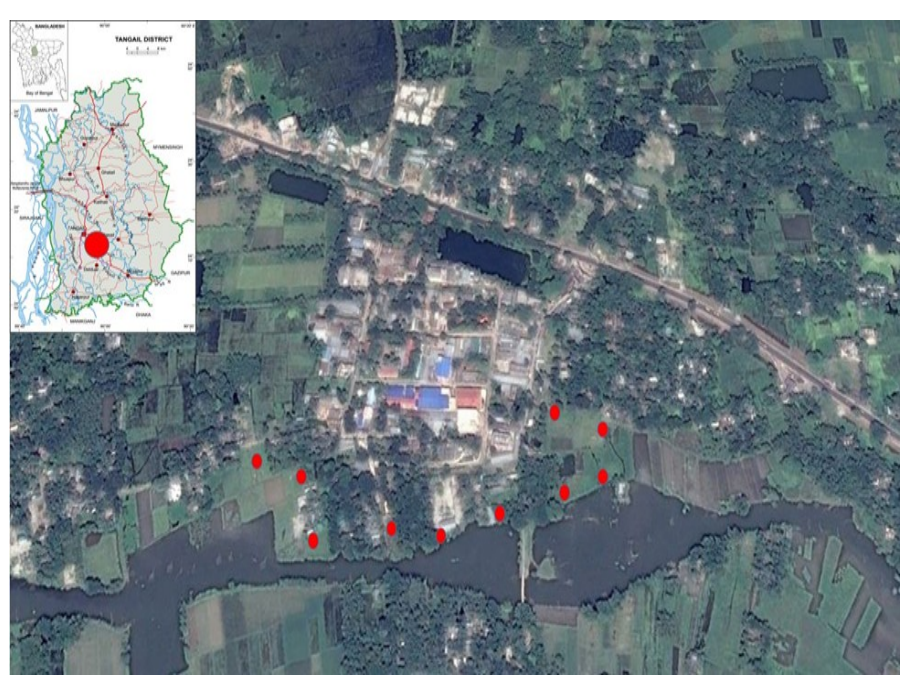

Figure 1. Map of the sampling sites of industrial areas in Tangail district, Bangladesh (red circle indicate sampling locations). 
After that, EC was measured using an EC meter (WTW LF 521; Germany). For organic carbon, $1.0 \mathrm{~g}$ of soil was placed at the bottom of a dry $500 \mathrm{~mL}$ conical flask (Corning/Pyrex). Then 10 $\mathrm{mL}$ of $1 \mathrm{~N} \mathrm{~K}_{2} \mathrm{Cr}_{2} \mathrm{O}_{7}$ was added into the conical flask and swirled a little. The flask was kept on asbestos sheet. Then $20 \mathrm{~mL}$ of concentrated $\mathrm{H}_{2} \mathrm{SO}_{4}$ was added into the conical flask and swirled again 2-3 times. The flask was allowed to stand for 30 minutes and thereafter $200 \mathrm{~mL}$ of distilled water was added. After incorporation of $5.0 \mathrm{~mL}$ of phosphoric acid and 35 drops of diphenylamine indicator, the contents were titrated against ferrous ammonium sulfate solution till the color flashes blue-violet to green. Simultaneously, a blank titration was run without soil. Particle size was determined using the hydrometer method. The textural classes for different soil samples were then determined by plotting the results on a triangular diagram designed by Marshall followed USDA system. The percentage of sand, silt and clay were calculated as follows:

$\%($ Silt + Clay $)=($ Corrected hydrometer reading at 40 seconds $/$ Oven dry weight of soil) $\times 100$

$\%($ Clay $)=($ Corrected hydrometer reading after 2 hours $/$ Oven dry weight of soil) $\times 100$

Sand $(\%)=100-\%($ Silt + Clay $)$

Silt $(\%)=\%($ Silt + Clay $)-\%$ Clay

Heavy metal analysis

All chemicals were analytical grade reagents; Milli-Q water (Elix UV5 and MilliQ, Millipore, Boston, MA, USA) was used for the preparation of solutions. The Teflon vessel and polypropylene containers were cleaned, soaked in $5 \% \mathrm{HNO}_{3}$ for more than 24 $\mathrm{h}$, then rinsed with Milli-Q water and dried. For metal analysis, 0.3-0.5 $\mathrm{g}$ of the soil sample was treated with $6 \mathrm{~mL} 69 \% \mathrm{HNO}_{3}$ (Kanto Chemical Co, Tokyo, Japan) and $2 \mathrm{~mL} 30 \% \mathrm{H}_{2} \mathrm{O}_{2}$ (Wako Chemical Co, Tokyo, Japan) in a closed Teflon vessel and was digested in a Microwave Digestion System (Berghof speedwave, Eningen, Germany). The digested samples were then transferred into a Teflon beaker, and total volume was made up to $50 \mathrm{~mL}$ with Milli-Q water. The digested solution was then filtered by using syringe filter (DISMIC1-25HP PTFE, pore size $=0.45 \mathrm{~mm}$; Toyo Roshi Kaisha, Ltd., Tokyo, Japan) and stored in $50 \mathrm{~mL}$ polypropylene tubes (Nalgene, New York, NY, USA). After that, the digestion tubes were then cleaned using blank digestion procedure following the same procedure of samples. For trace metals, samples were analyzed using inductively coupled plasma mass spectrometer (ICP-MS, Agilent 7700 series, Santa Clara, CA, USA). Instrument operating conditions and parameters for metal analysis were done. The detection limits of ICP-MS for the studied metals were 0.7, 0.6, 0.8, 0.4, 0.06 and $0.09 \mathrm{ng} / \mathrm{L}$ for $\mathrm{Cr}$, $\mathrm{Ni}, \mathrm{Cu}, \mathrm{As}, \mathrm{Cd}$ and $\mathrm{Pb}$, respectively. Multi-element Standard XSTC-13 (Spex CertiPrep ${ }^{\circledR}$, Metuchen, NJ, USA) solutions were used to prepare calibration curves. Multi-element solution (purchased from Agilent Technologies, Japan) was used as tuning solution covering a wide range of masses of elements. All test batches were evaluated using an internal quality approach and validated if they satisfied the defined Internal Quality Controls (IQCs). Before starting the analysis sequence, relative standard deviation (RSD, <5\%) was checked by using the tuning solution purchased from Agilent Technologies. The certified reference materials INCT-CF-3 bought from the National Research Council (Canada), were analyzed to confirm analytical performance and good precision (relative standard deviation below $20 \%$ ) of the applied method.

\section{Ecological risk assessment for soil pollution}

\section{Enrichment factor (EF)}

Enrichment factor (EF) is considered as an effective tool to evaluate the magnitude of contaminants in the environment (Franco-Uria et al., 2009). The EF for each element was calculated to evaluate anthropogenic influences on heavy metals in soils using the following formula (Selvaraj et al., 2004):

$$
\mathrm{EF}=\left(\mathrm{C}_{\mathrm{M}} / \mathrm{C}_{\mathrm{Al}}\right)_{\text {Sample }} /\left(\mathrm{C}_{\mathrm{M}} / \mathrm{C}_{\mathrm{Al}}\right)_{\text {Background }}
$$

Where, $\left(C_{M} / C_{A 1}\right)_{\text {sample }}$ is the ratio of concentration of heavy metal $\left(C_{M}\right)$ to that of aluminum $\left(C_{A l}\right)$ in the soil sample, and $\left(C_{M} /\right.$ $\left.\mathrm{C}_{\mathrm{Al}}\right)_{\mathrm{Background}}$ is the same reference ratio in the background sample. Generally, an EF value of about 1 suggests that a given metal may be entirely from crustal materials or natural weathering processes (Zhang and Liu, 2002). Samples having enrichment factor $>1.5$ was considered indicative of human influence and (arbitrarily) an EF of 1.5-3, 3-5, 5-10 and $>10$ is considered the evidence of minor, moderate, severe, and very severe modification (Birch and Olmos, 2008).

\section{Contamination factor $\left(\mathrm{C}_{\mathrm{f}}^{\mathrm{i}}\right)$}

Contamination factor means the proportion of the heavy metal concentration in the soil to that of baseline or background value:

$C_{f}^{i}=C_{\text {Heavy metal }} / C_{\text {Background }}$

Contamination factor divided into four classes ranged from 1 to 6 which are: low degree $\left(C_{f}^{i}<1\right)$, moderate degree $\left(1 \leq C_{f}^{i}<\right.$ $3)$, considerable degree $\left(3 \leq C_{f}^{i}<6\right)$, and very high degree $\left(C_{f}^{i} \geq\right.$ 6) (Islam et al., 2015c). This approach has been used by other researchers (e.g. Proshad et al., 2017a).

\section{Pollution load index}

To assess the quality of soil in terms of metal contamination, an integrated approach of pollution load index of the six metals is calculated according to Rashed (2010). The PLI is defined as the $n^{\text {th }}$ root of the multiplications of the contamination factor $\left(C_{f}^{i}\right)$ of metals (Bhuiyan et al., 2011). 


$$
P L I=\left(C_{f}^{i} \times C_{f_{2}}^{i} \times C_{f^{3}}{ }^{i} \times \ldots \ldots \times C_{f}{ }^{i}\right)^{1 / n}
$$

The PLI gave an assessment of the overall toxicity status of the sample and also it is a result of the contribution of the six metals. Therefore, PLI value of zero indicates perfection, a value of one indicates the presence of only baseline level of pollutants and values above one would indicate progressive deterioration of the site and estuarine quality. The PLI gave an assessment of the overall toxicity status of the sample and also it is a result of the contribution of the six metals.

\section{Potential ecological risk (PER)}

The degrees of hazardous elements contamination in agricultural soils are determined by PER index. Proposed equations which were used to calculate PER and are as follows (Luo et al., 2007; Guo et al., 2010).

$$
\begin{gathered}
C_{f}^{i}=\frac{C^{i}}{C_{n}^{i}}, \quad C_{d}=\sum_{i=1}^{n} C_{f}^{i} \\
E_{r}^{i}=T_{r}^{i} \times C_{f}^{i}, \quad P E R=\sum_{i=1}^{m} E_{r}^{i}
\end{gathered}
$$

Where, $C_{f}^{i}$ is the single element contamination factor, $C^{i}$ is the content of the element in samples and $C_{n}^{i}$ is the background value of the element. The background value of $\mathrm{Cr}, \mathrm{Ni}, \mathrm{Cu}, \mathrm{As}, \mathrm{Cd}$ and $\mathrm{Pb}$ in soils were $90,68,45,13,0.3$ and $20 \mathrm{mg} / \mathrm{kg}$, respectively (pre-industrial samples of the study area) (Turekian and Wedepohl, 1961). The sum of $C_{f}^{i}$ for all metals represent the integrated pollution degree $\left(C_{d}\right)$ of the environment. $C_{r}^{i}$ is the potential ecological risk index and $T^{i}$,is the biological toxic factor of an individual element. The toxic-response factors for $\mathrm{Cr}, \mathrm{Ni}$, $\mathrm{Cu}, \mathrm{As}, \mathrm{Cd}$ and $\mathrm{Pb}$ were 2, 6, 5, 10, 30 and 5, respectively (Håkanson, 1980; Luo et al., 2007; Wu et al., 2010; Guo et al., 2010; Jintao et al., 2011; Amuno, 2013). PER is the comprehensive potential ecological risk index, which is the sum of $E_{r}^{i}$. Sensitivity of the biological community is represented by it to the toxic substance and indicates the potential ecological risk caused by the overall contamination.

\section{Toxic unit analysis}

The sum of toxic units ( $\Sigma T U s$ ) is considered as potential acute toxicity of hazardous elements in agricultural soil samples. Toxic unit analysis is stated as the ratio of the assessed concentration of hazardous elements in soil to probable effect level (PELs) (Zheng et al., 2008). A moderate to serious toxicity of hazardous elements remain in soil when the sum of toxic units for all soil samples is more than 4 (Bai et al., 2011).

\section{Health risk assessment from polluted soil}

Daily intake of heavy metals through exposure pathway from soil

Ingestion and dermal absorption of heavy metals from polluted agricultural soils have great importance in potential exposure pathways (Fryer et al., 2006; Qu et al., 2012). Out of several exposure pathways, ingestion of metals from soil is the most common exposure pathway for $\mathrm{Cr}, \mathrm{Ni}, \mathrm{Cu}, \mathrm{As}, \mathrm{Cd}$ and $\mathrm{Pb}$ (Ordóñez et al., 2011). Chronic daily intake (CDI) (mg/kg/day) of metals was determined from ingestion ( $\left.C D I_{\text {ingest-soil }}\right)$ and dermal contact $\left(\mathrm{CDI}_{\text {dermal-soil }}\right)$ in the present study for both adult and children were estimated using the following formulas:

Ingestion from soil: $\mathrm{CDI}_{\text {ingest-soil }}=\frac{C S \times \mathrm{IRS} \times \mathrm{EF} \times \mathrm{ED}}{B W \times \mathrm{AT}} \times \mathrm{CF}$

Dermal contact from soil: $\mathrm{CDI}_{\text {dermal-soil }}=$

$$
\frac{C S \times \mathrm{SA} \times \mathrm{AF} \times \mathrm{ABS} \times \mathrm{IRS} \times \mathrm{EF} \times \mathrm{ED}}{B W \times \mathrm{AT}} \times \mathrm{CF}
$$

Inhalation from soil: $\mathrm{CDI}_{\text {inhalation-soil }}=$

$$
\frac{C S \times \mathrm{InhR} \times \mathrm{EF} \times \mathrm{ED}}{B W \times \mathrm{AT}} \times \mathrm{CF}
$$

Where, $\mathrm{CDI}$ = chronic daily intake; $\mathrm{CS}$ - exposure-point concentration: $\mathrm{mg} / \mathrm{kg}$; IRS-ingestion rate: 100 and $200 \mathrm{mgd}^{-1}$ for adult and children (USEPA, 2011); EF - exposure frequency: $350 \mathrm{~d} / \mathrm{a}$ (USEPA, 2011); ED - exposure duration: 30 years for adult, 6 years for children (USEPA, 2011); CF-units conversion factor: $10^{-6} \mathrm{~kg} \mathrm{mg}^{-1}$ (USEPA, 2002); SA - exposure skin area: 5700 and $1600 \mathrm{~cm}^{2}$ for adult and children (USEPA, 2011); AF - adherence factor: 0.07 and $0.02 \mathrm{mg} \cdot \mathrm{cm}^{-2}$ for adult and children (USEPA, 2011); ABS -dermal absorption fraction: 0.01 for adult and 0.001 for children (USEPA, 2011); BW - body weight: $70 \mathrm{~kg}$ for adult, $15 \mathrm{~kg}$ for children (USEPA, 2001); AT - averaging time for non-carcinogens: 365 × ED (USEPA, 2002); InhR - Inhalation rate $20 \mathrm{~m} 3 / \mathrm{d}$ for both adult and child (USEPA, 1997).

\section{Hazard Quotient (HQ)}

The non-carcinogenic risks for each individual heavy metal $(\mathrm{Cr}$, $\mathrm{Ni}, \mathrm{Cu}, \mathrm{As}, \mathrm{Cd}$ and $\mathrm{Pb}$ ) through ingestion, dermal and inhalation were assessed by the target hazard quotient (THQ) (USEPA, 1989). The methodology for the estimation of non-carcinogenic risks was applied in accordance with that provided by the U.S. Environmental Protection Agency (USEPA) Region III's riskbased concentration table (USEPA, 2011). Hazard quotient (HQ) was determined on the basis of chronic daily intake from ingestion ( $\left.\mathrm{CDI}_{\text {ingest }}\right)$ dermal $\left(\mathrm{CDI}_{\text {dermal }}\right)$ and inhalation $\left(\mathrm{CDI}\right.$ inhalation $\left._{\text {) }}\right)$ it was calculated by dividing the average daily dose to a specific reference dose (RfD) (USEPA, 1989). The equation used for estimating the target hazard quotient is as follows:

$$
\mathrm{HQ}_{\text {ingest }}=\left(\mathrm{CDI}_{\text {ingest }}\right) / \mathrm{RfD}
$$

$H Q_{\text {dermal }}=\left(C D I_{\text {dermal }}\right) /$ RfD

$\mathrm{HQ}_{\text {inhalation }}=\left(\mathrm{CDI}_{\text {inhalation }}\right) / \mathrm{RfD}$ 
Where, THQ is the target hazard quotient, CDI is the chronic daily intake of heavy metal $(\mathrm{mg} / \mathrm{kg}$ ) and $\mathrm{RfD}$ is reference dose (mg/kg/day). The RfD for $\mathrm{Cr}, \mathrm{Ni}, \mathrm{Cu}, \mathrm{As}, \mathrm{Cd}$ and $\mathrm{Pb}$ were 0.003 , $0.02,0.04,0.0003,0.0005$ and $0.0035 \mathrm{mg} / \mathrm{kg} /$ day, respectively (USDOE, 2011; USEPA, 2002). The reference dose (RfD) (mg/ $\mathrm{kg} /$ day) is an estimation of maximum permissible risk on human population through daily exposure, taking into consideration sensitive group (children) during the lifetime. If the CDI is higher than $\mathrm{RfD}(\mathrm{HQ}>1)$, there will be a severe health hazard to human, whereas $C D I$ is less than $\operatorname{RfD}(H Q \leq 1)$, there will be no severe human health effects (USEPA, 1989; USEPA, 2001). The health risk guidelines determination of chemical mixtures defined that "simultaneous sub-threshold exposures to several chemicals may result in an adverse health effect" and "the magnitude of the adverse effect will be proportional to the sum of the ratios of the sub-threshold exposures to acceptable exposures" (USEPA, 1986). Again, hazard index (HI) can be generated from the hazard quotient to calculate the combined risk of individual heavy metals in the form of mix contaminates (USEPA, 1989).

\section{Hazard Index (HI)}

In order to assess the overall potential for non-carcinogenic effects from more than one heavy metal, a hazard index (HI) has been formulated based on the guidelines for health risk assessment of chemical mixtures (USEPA, 1999). The hazard index (HI) from THQs is expressed as the sum of the hazard quotients (USEPA, 2011). The equation used for estimating the hazard index is as follows:

\section{$H I=\Sigma T T H Q_{n}$}

$$
\mathrm{HI}=\mathrm{TTHQ} \mathrm{element} \mathrm{1}+\mathrm{TTHQ} \mathrm{Q}_{\text {element 2 }}+\ldots \ldots \ldots . .+\mathrm{TTHQ} \mathrm{Q}_{\text {elements n }}
$$

$H I=\Sigma T T H Q=H i_{\text {ngest }}+H Q_{\text {dermal }}+H Q_{\text {inhalation }}$

The guidelines also state that any single metal with an exposure level greater than the toxicity value will cause the hazard index to exceed unity, for multiple metal exposures the $\mathrm{HI}$ can also exceed unity even if no single metal exposure exceeds its RfD.

\section{Carcinogenic risk}

Carcinogenic risk is considered as the probability of an individual developing any type of cancer in the whole lifetime due to exposure to carcinogenic hazards (Li et al., 2014). Carcinogenic risk expressed as the total cancer risk Eq. (22).

$$
C R_{\text {ingest-soilt }}=\{(C S \times A F \times I n g R \times E F \times E D) /(B W \times A T)\} \times C F \times C S F_{\text {ingest }}
$$
$\mathrm{CR}_{\text {dermal-soil }}=\left\{\left(\mathrm{CS} \times \mathrm{SA} \times \mathrm{AF} \times \mathrm{ABS}_{\mathrm{d}} \times \mathrm{EF} \times \mathrm{ED}\right) /(\mathrm{BW} \times \mathrm{AT})\right\} \times \mathrm{CF} \times \mathrm{CSF}_{\text {in- }}$
gest
$\times \mathrm{ABS}_{\mathrm{Gl}}$

$\mathrm{CR}_{\text {inhalation-soil }}=\{(\mathrm{CS} \times \mathrm{ET} \times \mathrm{EF} \times \mathrm{ED}) /(\mathrm{PEF} \times 24 \times \mathrm{AT})\} \times 1 \mathrm{UR} \times 10^{3}$
Total cancer risk $=\Sigma$ Cancer risk $=$ Risk $_{\text {ingestion }}+$ Risk $_{\text {dermal }}{ }^{+}$ Riskinhalation

Where, $\mathrm{CR}_{\text {ingest-soil }}-$ cancer risk of metals from ingestion of soil $\mathrm{CR}_{\text {dermal-soil }}$ - cancer risk of metals from dermal contact of soil; $\mathrm{CS}$ - heavy metal concentration in soil: $\mathrm{mg} / \mathrm{kg}$; $\mathrm{AF}$ - soil -toskin adherence factor: $0.7 \mathrm{mg} / \mathrm{cm}^{2}$ for adult and $0.2 \mathrm{mg} / \mathrm{cm}^{2}$ for children (USEPA, 2011); IngR-ingestion rate of soil: 100 and 200 mgd-1 for adult and children respectively (USEPA, 2011); EF - exposure frequency: 350 days/year (USEPA, 2011); ED exposure duration: 30 years for adult and 6 years for children (USEPA, 2011); BW - body weight: $70 \mathrm{~kg}$ for adult and $15 \mathrm{~kg}$ for children; AT - averaging time for non-carcinogens: $365 \times$ ED (USEPA, 2011); CF-units conversion factor: $10^{-6} \mathrm{~kg} / \mathrm{mg}$ (USEPA, 2002); CSF $_{\text {ingest }}-$ Chronic oral slope factor: 1.5 for As and $8.5 \times 10^{-3}$ for Pb (USEPA, 2010; USDOE, 2011); SA - exposure skin surface area available for contact: $5700 \mathrm{~cm}^{2}$ for adult and $1600 \mathrm{~cm}^{2}$ for children (USEPA, 2011); $\mathrm{ABS}_{\mathrm{d}}$ - dermal absorption fraction: 0.01 for adult and 0.001 for children (USEPA, 2011); ET- Exposure time: 1 for residents for the site specific (USDOE, 2011); $\mathrm{ABS}_{\mathrm{Gl}}$-Gastrointestinal absorption factor: 0.41 and 1 for $A s$ and $\mathrm{Pb}$ respectively (USEPA, 2011); PEF-Particle emission factor: $1.36 \times 10^{9}$ (USDOE, 2011; USEPA, 2011); IUR-Chronic inhalation unit risk: $4.30 \times 10^{-3}$ for As, $1.20 \times 10^{-5}$ for adult (USDOE, 2011).

In present study, we calculated carcinogenic risk for arsenic and lead as they are classified as probably carcinogenic to humans (ASTDR, 2007; ATSDR, 2012). The excess cancer risks lower than $10^{-6}$ (a probability of 1 chance in 1,000,000 of an individual developing cancer) are considered to be negligible, cancer risks above $10^{-4}$ are considered unacceptable by most international regulatory agencies (USEPA, 1989; Guney et al., 2010) and risks lying between $10^{-6}$ and $10^{-4}$ are generally considered an acceptable range, depending on the situation and circumstances of exposure (Hu et al., 2012). The value $10^{-6}$ is also considered the carcinogenic target risk (USEPA, 2011).

\section{Statistical analysis}

The data were statistically analysed using the statistical package, SPSS 20.0 (SPSS, USA). The means of the hazardous element concentrations in soils were calculated. Other calculations were performed by Microsoft Excel 2013.

\section{RESULTS AND DISCUSSION}

Heavy metals pollution in agricultural soils of industrial area is a great concern and affects soil health. Polluted soils in the industrial areas are greatly responsible for environmental pollution with human health inferences. Heavy metals are too toxic to affect soil health as well as human health. Crop production may be affected by the presence of heavy metals in soils, their storage in soil and transformation. Heavy metals affect human, animal and plant health (VROM, 2000). The concentration of heavy metals for present the study was lower than the Dutch standard (VROM, 2000), Australian guidelines (DEP, 2003) and 
Canadian guidelines (CCME, 2003) except cadmium. Cadmium concentration for the present study was higher than the Dutch standard (VROM, 2000) and Canadian guidelines (CCME, 2003). Environmental action level demonstrates that the low risk to environment and human health.

Physicochemical properties and heavy metals concentration in soils

The studied soils $\mathrm{pH}$ values were ranged from 5.58 to 6.67 indicating that soils were slightly acidic (Table 1 ). The studied soils were acidic to neutral because of decomposition of organic matter and subsequent formation of carbonic acid (Ahmad et al., 1996). Higher soil acidity favors the availability of cations in soil. Soil pH (acidity) is of particular importance as it controls the behavior of metals and many other soil processes. Heavy metal cations (positively charged metal atoms) are most mobile in acid soils. This means that metal contaminants are more available for uptake by plants, or to move into the water supply (Oliver, 1997; Adeniyi et al., 2008). Electrical conductivity (EC) value of the studied soil was non-saline (0-2 dS/m; SRDI soil salinity class) for all sampling sites which mean the salinity effect is negligible (SRDI, 2009). The range of organic carbon (\% C) was 0.504 to 4.310 , where the highest value was observed in soil collected from the S10 site and lowest value observed in S1 site. High organic carbon content is an indication that metals are more likely to be bound to organic matter to form metal chelate complexes, and this would also result in less availability of metals to plants (Yap et al., 2009). According to the United States soil texture classification system (Soil Survey Division Staff, 1993), the textural analysis revealed that the studied soil samples were loam (Table 1).

The mean concentrations of $\mathrm{Cr}, \mathrm{Ni}, \mathrm{Cu}, \mathrm{As}, \mathrm{Cd}$, and $\mathrm{Pb}$ in agricultural soils were found 5.88, 13.92, 18.07, 5.9, 2.19, and $8.08 \mathrm{mg} /$ $\mathrm{kg}$, respectively (Table 2 ) around the industrial vicinity of Tangail district, Bangladesh. The highest $\mathrm{Cr}$ concentration was observed at 13.41 and $10.95 \mathrm{mg} / \mathrm{kg}$ at $\mathrm{S}_{1}$ and $\mathrm{S}_{4}$ sampling sites in the present study. A considerable amount of $\mathrm{Cr}$ was observed in soil collected from the agricultural field near industrial areas of Tangail district which might be due to the use of tannery waste for the supplement of organic matter for crop production. Agricultural field may receive $\mathrm{Cr}$ from the unplanned activities of tannery industries in Tangail City. The mean concentration of $\mathrm{Cr}$ was found $5.88 \mathrm{mg} / \mathrm{kg}$ in the present study which was lower than The Dutch Soil Quality Standard (VROM, 2000), Canadian Environmental Quality Guidelines (CCME, 2003) and Australian Guideline for Soil Quality (DEP, 2003) indicating lower contamination of $\mathrm{Cr}$ in soil (Table 3). Chromium is a toxic heavy metal is discharged from several industries into the agricultural land around industrial areas and pollutes agricultural soils (Nriagu, 1988). Cr concentration was found in the study areas may be disposed of untreated tannery waste to agricultural fields since chromium salt used in tannery industries (Srinivasa et al., 2010). The concentration of $\mathrm{Cr}$ in agricultural soils varies up to values as high as $350 \mathrm{mg} / \mathrm{kg}$ (Branca et al., 1990). Chromium concentration in the present study was lower than other studies
(Tokalığlu and Kartal, 2006; Bhagure and Mirgane, 2011; Acosta et al., 2011; Islam et al., 2014; Islam et al., 2015a, 2017; Proshad et al., 2018b) conducted different areas in Bangladesh and other countries. The toxicity of $\mathrm{Cr}$ has negative impacts on the growth of plants that interfere with some important metabolic processes (Panda and Patra, 2000; Panda, 2007; Yu et al., 2008; Shaker et al., 2009; Hasnine et al., 2017).

Nickel can cause dermatitis, lung fibrosis, cardiovascular and kidney diseases and cancer of the respiratory tract in the human body (Hasnine et al., 2017). The solubility of nickel in soils increases with its acidity and if the acidity increases it results higher $\mathrm{Ni}$ in soils (Baralkiewicz and Siepak, 1999). In the present study $\mathrm{Ni}$ concentrations ranged between $3.01-25.92 \mathrm{mg} / \mathrm{kg}$ in the study area. The highest amount $(25.92 \mathrm{mg} / \mathrm{kg})$ was found in station 1 and the lowest value $(3.01 \mathrm{mg} / \mathrm{kg}$ ) in station 9 (Table 2). The elevated levels of $\mathrm{Ni}$ were found in station 1 which results from localized additions or accidental spillages of $\mathrm{Ni}$ containing materials (Krishna and Govil, 2007). The mean concentration of Ni was found $13.92 \mathrm{mg} / \mathrm{kg}$ in the present study which was lower than The Dutch Soil Quality Standard (VROM, 2000), Canadian Environmental Quality Guidelines (CCME, 2003) and Australian Guideline for Soil Quality (DEP, 2003) indicating lower contamination of $\mathrm{Ni}$ in soil (Table 2). Nickel ( $\mathrm{Ni}$ ) concentration in the present study was lower than other studies (Tokalıoglu and Kartal, 2006; Bhagure and Mirgane, 2011; Acosta et al., 2011; Islam et al., 2014; Islam et al., 2015a, 2017; Proshad et al., 2018b) conducted different areas in Bangladesh and other countries. USPHS (1997), Alloway (1990) reported that the typical concentration of $\mathrm{Ni}$ in soil is $50 \mathrm{mg} / \mathrm{kg}$. Hasnine et al. (2017) reported average $\mathrm{Ni}$ concentration in the surface agricultural soil at DEPZA was found to be $655.53 \pm 979.73 \mathrm{mg} / \mathrm{kg}$. Dojlido and Best (1993) found approximately $26,000 \mathrm{mg} / \mathrm{kg} \mathrm{Ni}$ of highly developed nickel smelting in Canada. $250 \mathrm{mg} / \mathrm{kg}$ Ni was determined in a highly polluted area contaminated by galvanization plant sewage (Dojlido and Best, 1993). The concentration of $\mathrm{Ni}$ in the agricultural soils of Ontario varied between 1.3 to 6,560 $\mathrm{mg} / \mathrm{kg}$ (Frank et al., 1976).

Excessive $\mathrm{Cu}$ concentrations are harmful to plants and highly toxic to some microorganisms (Hasnine et al., 2017). Soluble soil $\mathrm{Cu}$ can be toxic to plants since $\mathrm{Cu}$-enriched liquid dairy waste used in agricultural land as irrigation water (White and Brown, 2010). In the present study, the value of $\mathrm{Cu}$ ranged between 3.86 to $78.11 \mathrm{mg} / \mathrm{kg}$ (Table 2). The elevated concentration of $\mathrm{Cu}$ was observed in soil from waste disposal sites which can be due to the emission of $\mathrm{Cu}$ from the uncontrolled industrial and waste burning activities (Kashem and Singh, 1999; Srinivasa et al., 2010; Luo et al., 2011). The mean concentration of Cu was found $18.07 \mathrm{mg} / \mathrm{kg}$ in the present study which was lower than The Dutch Soil Quality Standard (VROM, 2000), Canadian Environmental Quality Guidelines (CCME, 2003) and Australian Guideline for Soil Quality (DEP, 2003) indicating lower contamination of $\mathrm{Cu}$ in soil (Table 2). Alloway (1990) provided with the regulatory standard for $\mathrm{Cu}$ in soil is $20-30 \mathrm{mg} / \mathrm{kg}$. Cu concentration in the present study was compared to other studies conducted in 
Bangladesh and other countries. Present studied Cu concentrations were lower than other studies (Tokalıoglu and Kartal, 2006; Bhagure and Mirgane, 2011; Acosta et al., 2011; Islam et al., 2014; Islam et al., 2015a, 2017; Proshad et al., 2018b). Frank et al. (1976) documented the value of Cu ranged from 2.1 to 664 $\mathrm{mg} / \mathrm{kg}$ in agricultural soils of Ontario. Sonmez et al. (2006) reported decrease height in plant, total yield, number of fruit, and dry root weight with increasing Cu application. Yu et al. (2008) found $17.10 \mathrm{mg} / \mathrm{kg} \mathrm{Cu}$ in arid agricultural soil in central Gansu Province, China. The threshold value for $\mathrm{Cu}$ is $\leq 60 \mathrm{mg} / \mathrm{kg}$ for arid agricultural soils in China (NEPA, 1995). Hasnine et al. (2017) reported average Cu concentration in the surface agricultural soil at DEPZA was found to be $91.06 \pm 152.70 \mathrm{mg} / \mathrm{kg}$. In the present study, the concentration of As varied between 1.56 to $28.30 \mathrm{mg} / \mathrm{kg}$ (Table 2). A huge amount of groundwater containing As (Neumann et al., 2010; Hug et al., 2011) is being used for tanning in relation to some chemicals especially arsenic sulfide (Asaduzzaman et al., 2002; Bhuiyan et al., 2011). Moreover, emission and waste from brick fields and incineration activities might contribute to the high concentration of As (Olawoyin et al., 2012). Arsenic in agricultural soils can be derived from both natural and anthropogenic sources, especially use of groundwater for irrigation and uncontrolled application of As enriched fertilizers and pesticides (Renner, 2004; Neumann et al., 2011). All the concentrations of As found to below the recommended value set by The Dutch Soil Quality Standard (VROM, 2000) (Table 2). Present studied As concentrations were lower than other studies (Proshad et al., 2017a; Islam et al., 2014, 2015a, 2017). Frank et al. (1976) estimated 6.21 2.67 $\mathrm{mg} / \mathrm{kg}$ As in agricultural soils of Ontario while Yu et al. (2008) recorded $8.80 \mathrm{mg} / \mathrm{kg}$ As in arid agricultural soil in central Gansu Province, China. The threshold value for As is $\leq 20 \mathrm{mg} / \mathrm{kg}$ for arid agricultural soils in China (NEPA, 1995). As contaminated water and As-enriched fertilizers as well as pesticides were used for irrigation in the agricultural land (Alam et al., 2003; Polizzotto et al., 2013). Moreover, emission and waste from brick fields and incineration activities might contribute to the high concentration of As in agricultural soil (Olawoyin et al., 2012).

Cadmium concentrations were found between 0.36 to $7.53 \mathrm{mg} /$ kg. The mean concentration of $\mathrm{Cd}$ was found $2.19 \mathrm{mg} / \mathrm{kg}$ in the present study which was lower than The Dutch Soil Quality Standard (VROM, 2000) and Canadian Environmental Quality

Table 1. Physiochemical properties of soil collected from agricultural field in the industrial areas of Tangail district, Bangladesh.

\begin{tabular}{lccccccc}
\hline Sampling sites & $\mathrm{pH}\left(1: 2.5 \mathrm{H}_{\mathbf{2}} \mathrm{O}\right)$ & $\mathrm{EC}(\mathrm{dS} / \mathrm{m})$ & Organic carbon $(\%)$ & Sand $(\%$ in $<2 \mathrm{~mm})$ & Silt & Clay $^{\text {Soil type }}$ \\
\hline $\mathrm{S}_{1}$ & 6.62 & 0.08 & 0.504 & 37.6 & 46.6 & 15.8 & Loam \\
$\mathrm{S}_{2}$ & 5.58 & 0.15 & 0.506 & 34.9 & 47.5 & 17.6 & Loam \\
$\mathrm{S}_{3}$ & 6.11 & 0.12 & 0.506 & 44.7 & 40 & 15.3 & Loam \\
$\mathrm{S}_{4}$ & 5.82 & 0.33 & 0.522 & 36.5 & 45 & 18.5 & Loam \\
$\mathrm{S}_{5}$ & 6.87 & 0.15 & 2.582 & 37.6 & 44.1 & 18.3 & Loam \\
$\mathrm{S}_{6}$ & 6.38 & 0.13 & 0.578 & 31.5 & 46.6 & 21.9 & Loam \\
$\mathrm{S}_{7}$ & 6.38 & 0.21 & 0.746 & 42.2 & 37.5 & 20.3 & Loam \\
$\mathrm{S}_{8}$ & 6.54 & 0.08 & 0.750 & 37.5 & 47.4 & 15.1 & Loam \\
$\mathrm{S}_{9}$ & 6.24 & 0.11 & 0.820 & 41.5 & 41.6 & 16.9 & Loam \\
$\mathrm{S}_{10}$ & 6.2 & 0.09 & 4.310 & 43.5 & 44.1 & 12.4 & Loam \\
\hline
\end{tabular}

${ }^{a}$ According to the United states Department of Agriculture soil classification system.

Table 2. Metal concentration $(\mathrm{mg} / \mathrm{kg}$ ) in soil collected from agricultural field in the industrial areas of Tangail district, Bangladesh.

\begin{tabular}{lcccccc}
\hline Sampling sites & $\mathrm{Cr}$ & $\mathrm{Ni}$ & $\mathrm{Cu}$ & $\mathrm{As}$ & $\mathrm{Cd}$ & $\mathrm{Pb}$ \\
\hline $\mathrm{S}_{1}$ & 13.41 & 25.92 & 2.91 & 2.64 & 2.53 & 2.18 \\
$\mathrm{~S}_{2}$ & 6.05 & 9.40 & 78.11 & 28.30 & 7.53 & 17.93 \\
$\mathrm{~S}_{3}$ & 9.40 & 27.69 & 5.13 & 2.32 & 1.15 & 8.54 \\
$\mathrm{~S}_{4}$ & 10.95 & 18.95 & 26.64 & 13.22 & 3.05 & 18.32 \\
$\mathrm{~S}_{5}$ & 1.67 & 7.09 & 3.86 & 2.48 & 0.88 & 3.82 \\
$\mathrm{~S}_{6}$ & 1.09 & 3.35 & 8.66 & 2.38 & 3.58 & 7.37 \\
$\mathrm{~S}_{7}$ & 1.93 & 3.47 & 21.54 & 1.56 & 0.36 & 6.65 \\
$\mathrm{~S}_{8}$ & 7.04 & 26.77 & 19.21 & 1.59 & 1.88 & 10.84 \\
$\mathrm{~S}_{9}$ & 5.07 & 3.01 & 8.66 & 2.15 & 0.63 & 4.03 \\
$\mathrm{~S}_{10}$ & 2.24 & 13.63 & 6.03 & 2.38 & 0.37 & 1.19 \\
Mean $_{\text {Dutch standard }}{ }^{\mathrm{a}}$ & 5.88 & 13.92 & 18.07 & 5.90 & 2.19 & 8.08 \\
Canadian guidelines $^{\mathrm{b}}$ & 100 & 35 & 36 & 29 & 0.80 & 85 \\
Australian guidelines $^{\mathrm{c}}$ & 64 & 50 & 63 & 12 & 1.4 & 70 \\
\hline
\end{tabular}

${ }^{a} \operatorname{VROM}(2000)^{b}$ CCME (2003) ${ }^{\text {CDEP }(2003)}$ 
Guidelines (CCME, 2003) but higher than Australian Guideline for Soil Quality (DEP, 2003). Cd pollution has been reported from areas surrounding smelters in many countries (Martley et al., 2004; Rawlins et al., 2006). Cadmium (Cd) concentration in the present study was compared to other studies conducted in Bangladesh and other countries. Present studied Cd concentrations were lower than other studies (Tokalıoglu and Kartal, 2006; Bhagure and Mirgane, 2011; Acosta et al., 2011; Islam et al., 2014; Islam et al., 2015a, 2017; Proshad et al., 2018b). Frank et al., (1976) documented $0.5 \pm 0.69 \mathrm{mg} / \mathrm{kg} \mathrm{Cd}$ in agricultural soils of Ontario. 0.5 \pm 0.69 . The soil is considered clean if any heavy metal concentration in soil is below its respective Dutch Target Value. The soil is regarded to be slightly to moderately contaminated if the concentration level lies between the target values and intervention values. In contrast, if the value is above the Dutch Intervention Value, the soil is considered detrimental to humans, plants, and animals. About $70 \%$ of the studied soil samples exceeded the Dutch target value assuming that $\mathrm{Cd}$ in soil might pose a severe risk to the surrounding ecosystems.

The highest concentration of $\mathrm{Pb}$ was $18.32 \mathrm{mg} / \mathrm{kg}$ found on station 4. This level of $\mathrm{Pb}$ concentration present in soil due to metal processing factories release $\mathrm{Pb}$ into the open environment and several anthropogenic factors (Karim et al., 2008; Nziguheba and Smolders, 2008). In the present study, station 4 showed the elevated concentrations of $\mathrm{Pb}$ which can be due to the emission of $\mathrm{Pb}$ contaminated waste from these sites (Srinivasa et al., 2010). The mean concentration of $\mathrm{Pb}$ was found $8.08 \mathrm{mg} / \mathrm{kg}$ in the present study which was lower than The Dutch Soil Quality Standard (VROM, 2000), Canadian Environmental Quality Guidelines (CCME, 2003) and Australian Guideline for Soil Quality (DEP, 2003) indicating lower contamination of $\mathrm{Pb}$ in soil (Table 2). Lead $(\mathrm{Pb})$ concentration in the present study was lower than other studies (Tokalıoğlu and Kartal, 2006; Bhagure and Mirgane, 2011; Acosta et al., 2011; Islam et al., 2014; Islam et al., 2015a, 2017; Proshad et al., 2018b) conducted different areas in Bangladesh and other countries. Yu et al., (2008) recorded $23.30 \mathrm{mg} / \mathrm{kg} \mathrm{Pb}$ in arid agricultural soil in central Gansu Province, China. The threshold value for $\mathrm{Pb}$ is $\leq 50 \mathrm{mg} / \mathrm{kg}$ for arid agricultural soils in China (NEPA, 1995). Frank et al. (1976) recorded value for $\mathrm{Pb}$ that ranged between 1.5 to 888 $\mathrm{mg} / \mathrm{kg}$ in agricultural soils of Ontario.

Correlation coefficient matrix for physicochemical properties of soil and heavy metals

The results highlighted close association among correlation coefficient matrix for physiochemical properties of soil and heavy metals collected from industrial vicinity of Tangail district (Table 4). The value of $\mathrm{pH}$ showed significant negative correlation with $\mathrm{Cu}(\mathrm{r}$ $\left.=-0.73^{*}\right)$, As $\left(r=-0.78^{*}\right)$ and $\mathrm{Pb}(r=-0.72 *)$. Electrical conductivity, organic carbon, clay, nickel and cadmium didn't show any significant positive and negative correlations. Sand showed a significant negative correlations with silt $\left(r=-0.75^{*}\right)$ and cadmium $\left(r=-0.69^{*}\right)$. There were also showed others positive correlations like silt with $\mathrm{Cd}\left(r=0.63^{*}\right)$, Cr with $\mathrm{Ni}\left(r=0.78^{*}\right)$, Cu with As $\left(r=0.93^{* *}\right)$, Cu with $\mathrm{Cd}\left(r=0.83^{* *}\right)$, Cu with $\mathrm{Pb}\left(r=0.77^{* *}\right)$, As with $\mathrm{Cd}\left(\mathrm{r}=0.88^{* *}\right)$, As with $\mathrm{Pb}\left(r=0.77^{* *}\right)$. Considering the relationship between the combinations showed positive significant relationship which indicates the parameters were interrelated with each other and may be originated from the same source to the study area. Other relationships among the constituents of soil were not significant.

\section{Ecological risk assessment}

Ecological risk assessment for heavy metals contamination in soil was performed following the methodology developed by

Table 3. Comparison of metal concentration $(\mathrm{mg} / \mathrm{kg})$ in soil of the present study with other studies and guideline values.

\begin{tabular}{|c|c|c|c|c|c|c|c|}
\hline District (Country) & $\mathrm{Cr}$ & $\mathrm{Ni}$ & $\mathrm{Cu}$ & As & $\mathrm{Cd}$ & $\mathrm{Pb}$ & References \\
\hline Tangail, Bangladesh & 5.88 & 13.93 & 18.08 & 5.9 & 2.2 & 8.09 & Present study* \\
\hline Tangail, Bangladesh & 10.41 & 12.69 & 15.66 & 12.15 & 3.1 & 7.98 & Proshad et al., 2017a \\
\hline Tangail, Bangladesh & 8.31 & 16.49 & 20.64 & 5.06 & 2.2 & 16.9 & Proshad et al., 2018b \\
\hline Dhaka, Bangladesh & $158-1160$ & $104-443$ & $157-519$ & $41-93$ & $3.9-13$ & $84-574$ & Islam et al., 2014 \\
\hline Dhaka, Bangladesh & $2.4-1258$ & $8.3-1044$ & $9.7-823$ & $8.7-277$ & $1.8-80$ & $13-842$ & Islam et al., 2017 \\
\hline Bogra (Bangladesh) & $6.3-256$ & $8.3-271$ & $13-279$ & $7.5-87$ & $0.09-29$ & $5.3-624$ & Islam et al., 2015a \\
\hline Maharashtra (India) & 164 & 171 & 155 & 2.8 & 30 & 42 & $\begin{array}{l}\text { Bhagure and Mirgane, } \\
2011\end{array}$ \\
\hline Murcia (Spain) & 18 & 14 & 11 & NA & 0.22 & 49 & Acosta et al., 2011 \\
\hline Kayseri (Turkey) & 29 & 45 & 37 & NA & 2.5 & 75 & $\begin{array}{l}\text { Tokalıoğlu and Kartal, } \\
2006\end{array}$ \\
\hline $\begin{array}{l}\text { Dutch soil quality } \\
\text { standard (Target Value) }\end{array}$ & 100 & 35 & 36 & 29 & 0.8 & 85 & VROM, 2000 \\
\hline $\begin{array}{l}\text { Dutch soil quality } \\
\text { standard (Intervention } \\
\text { Value) }\end{array}$ & 380 & 210 & 190 & 55 & 12 & 530 & VROM, 2000 \\
\hline $\begin{array}{l}\text { Canadian Environmental } \\
\text { Quality Guidelines }\end{array}$ & 64 & 50 & 63 & 12 & 1.4 & 70 & CCME, 2003 \\
\hline $\begin{array}{l}\text { Department of Environ- } \\
\text { mental Protection, } \\
\text { Australia }\end{array}$ & 50 & 60 & 60 & 20 & 3 & 300 & DEP, 2003 \\
\hline
\end{tabular}


Hakanson (1980). In the present study, enrichment factor (EF), contamination factor $(C F)$, degree of contaminations $\left(C_{d}\right)$, pollution load index (PLI), potential ecological risk (PER) and toxic units have been applied to assess the contamination of heavy metals in soil of Tangail district.

For all sampling sites, enrichment factors of $\mathrm{Cr}$, $\mathrm{Ni}$ and $\mathrm{Pb}$ in soils were less than 1.5 (Figure 2, 3). About $10 \%$ of soil samples for $\mathrm{Cu}$ and $\mathrm{As}$ and $40 \%$ of $\mathrm{Cd}$ were higher than 1.5 indicating strong human influence from industrial pollution (Rashed, 2010). This research addressed that crusted source to the soil was the main reason of low enrichment of heavy metals and great contribution from anthropogenic sources resulting from high enrichment factors in soils (Rashed, 2010). The mean enrichment factors of $\mathrm{Cr}, \mathrm{Ni}, \mathrm{Cu}, \mathrm{As}, \mathrm{Cd}$ and $\mathrm{Pb}$ were 0.113, 0,244, 0.375, 0.509, 1.503 and 0.197 respectively. Here only $\mathrm{Cd}$ exceeds the standard value of enrichment and $\mathrm{Cd}$ have strong human influence from industrial contamination on soils.

Contamination factors of heavy metals for the present study were presented in Table 5. Present study indicates four types of contamination factors $\left(C_{f}^{i}\right)$ and four types of degree of contamination (Cd) (Håkanson, 1980). The contamination factors $\left(C_{f}^{i}\right)$ and four types of degree of contamination $(\mathrm{Cd})$ were presented in Table 6. The contamination level for the present study was found low to considerable indicating low to considerable contamination of heavy metals in soil. According to the contamination factor, $\mathrm{Cr}$, $\mathrm{Ni}$, and $\mathrm{Pb}$ showed low contamination. $\mathrm{Cu}$ and $\mathrm{As}$ showed low to moderate contamination. Only $\mathrm{Cd}$ showed low to considerable contamination (Table 5). In the present study, contamination factor values $\left(C_{f}^{i}\right)$ existed in the decreasing order of $\mathrm{Cd}>\mathrm{As}>\mathrm{Cu}>\mathrm{Ni}$ $>\mathrm{Pb}>\mathrm{Cr}$ in soils of different sampling sites in Tangail district.

Pollution load index (PLI) value equal to zero indicates nonpolluted; value of unity indicates the presence of only baseline level of pollutants and values above unity indicates progressive deterioration due to trace element pollution (Rashed, 2010;
Suresh et al., 2011). The extent of pollution increases with the increase of numerical PLI value. According to above grade, only cadmium (Cd) exceeds the standard value (Figure 4). Other metals showed less pollution load index indicating low contamination. The main reason for high cadmium pollution may be waste from different industries in the agricultural soil, tannery and dyeing industry had caused some extent risk of the studied area (Bhuiyan et al., 2010). The pollution load index values of the present study were in the decreasing order of $\mathrm{Cd}>\mathrm{As}>\mathrm{Cu}>\mathrm{Ni}>$ $\mathrm{Pb}>\mathrm{Cr}$ (Figure 4).

Potential ecological risk for the present study was calculated on the basis of five categories of risk index of individual metal $\left(E_{r}^{i}\right)$ and potential ecological risk index of the environment (PER) (Table 7) with their grade classifications (Luo et al., 2007). Studied area soil samples indicate the moderate to very high risk which must possess ecological hazard in the studied vicinity. For individual metal ecological risk assessment, cadmium showed the highest risk and the studied vicinity soils resulted from moderate, considerable and very high potential ecological risk due to combining toxic metal effects. Cd contributes significantly to the potential ecological risk index of the environment (PER) which can be due to the effect from anthropogenic activities such as application of phosphate fertilizers and industrial activities (ATSDR, 2008; Mass et al., 2011; Rodríguez Martín et al., 2013). Considering the potential ecological risk factor $\left(E_{r}^{i}\right)$ for the individual element, $\mathrm{Cd}$ showed very high potential ecological risk with the $E_{r}^{i}$ factor ranging between 56.73 to 1189.67 (Table 6). The order of $E_{r}^{i}$ for studied soil sample followed the decreasing order of $\mathrm{Cd}>\mathrm{As}>\mathrm{Cu}>\mathrm{Ni}>\mathrm{Pb}>\mathrm{Cr}$. Potential risk for present study ranged from 87.80 to 1422.97 .

Potential acute toxicity of hazardous elements in soil samples can be estimated as the sum of toxic units ( $\Sigma T U s$ ), considered as ecological risk. Toxic unit determines how much the soils were toxic by the accumulation of heavy metals (Zheng et al., 2008).

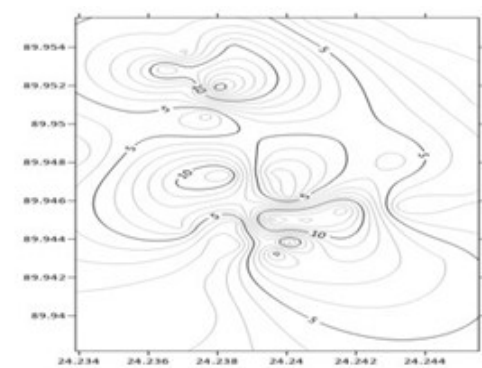

a. Chromium

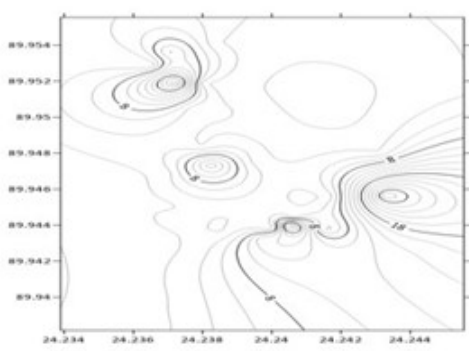

d. Arsenic

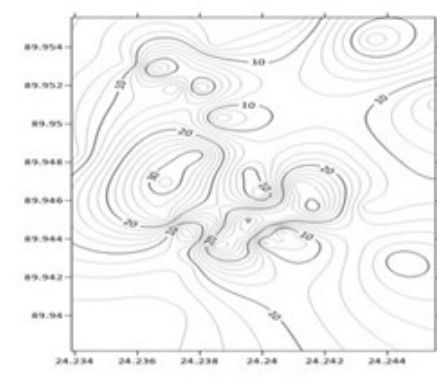

b. Nickel

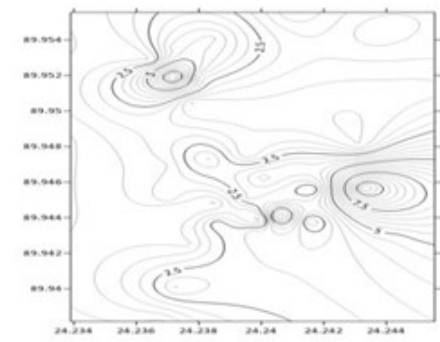

e. Cadmium

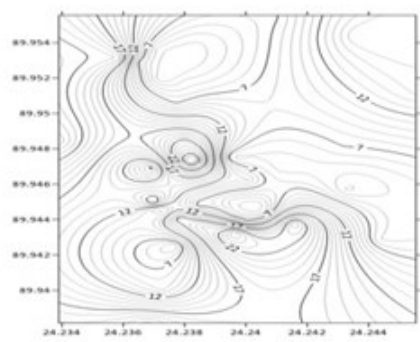

c. Cupper

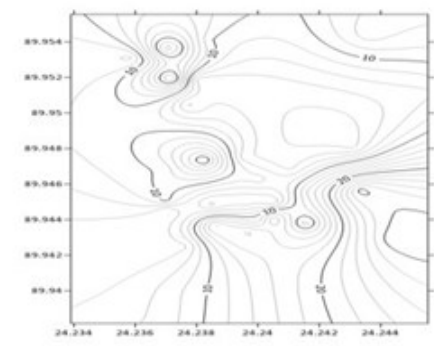

f. Lead

Figure 2. Distribution of heavy metals concentration in the soil samples of the study area. 
Table 4. Correlation coefficient matrix for physiochemical properties of soil and heavy metals.

\begin{tabular}{|c|c|c|c|c|c|c|c|c|c|c|c|c|}
\hline & $\mathrm{pH}$ & EC & Organic carbon & Sand & Silt & Clay & $\mathrm{Cr}$ & $\mathrm{Ni}$ & $\mathrm{Cu}$ & As & $\mathrm{Cd}$ & $\mathrm{Pb}$ \\
\hline $\mathrm{pH}$ & 1 & & & & & & & & & & & \\
\hline EC & -0.42 & 1 & & & & & & & & & & \\
\hline $\begin{array}{l}\text { Organic } \\
\text { carbon }\end{array}$ & 0.24 & -0.24 & 1 & & & & & & & & & \\
\hline Sand & 0.032 & -0.16 & 0.35 & 1 & & & & & & & & \\
\hline Silt & -0.061 & -0.204 & -0.25 & $-0.75^{*}$ & 1 & & & & & & & \\
\hline Clay & 0.27 & 0.49 & -0.49 & -0.58 & -0.097 & 1 & & & & & & \\
\hline $\mathrm{Cr}$ & -0.22 & 0.105 & -0.48 & -0.032 & 0.22 & -0.32 & 1 & & & & & \\
\hline $\mathrm{Ni}$ & 0.007 & -0.17 & -0.16 & 0.19 & 0.24 & -0.59 & $0.78^{*}$ & 1 & & & & \\
\hline $\mathrm{Cu}$ & $-0.73^{*}$ & 0.28 & -0.301 & -0.35 & 0.302 & 0.16 & 0.043 & -0.18 & 1 & & & \\
\hline As & $-0.78^{*}$ & 0.36 & -0.24 & -0.39 & 0.39 & 0.109 & 0.18 & -0.077 & $0.93^{* *}$ & 1 & & \\
\hline $\mathrm{Cd}$ & -0.606 & 0.14 & -0.42 & $-0.69^{*}$ & $0.63^{*}$ & 0.25 & 0.21 & -0.015 & $0.83^{* *}$ & $0.88^{* *}$ & 1 & \\
\hline $\mathrm{Pb}$ & $-0.72^{*}$ & 0.61 & -0.52 & -0.41 & 0.28 & 0.27 & 0.29 & 0.13 & $0.77^{* *}$ & $0.77^{* *}$ & 0.705 & 1 \\
\hline
\end{tabular}

${ }^{*}=$ Correlation is significant at the 0.05 level (two-tailed) ${ }^{* *}=$ Correlation is significant at the 0.01 level (two-tailed)

Table 5. Contamination factors, degree of contamination and contamination level in soil.

\begin{tabular}{|c|c|c|c|c|c|c|c|c|}
\hline \multirow{2}{*}{ Sites } & \multicolumn{6}{|c|}{ Contamination factors $\left(C_{f}^{i}\right)$} & \multirow{2}{*}{$\begin{array}{l}\text { Degree of contamination } \\
\left(C_{d}\right)\end{array}$} & \multirow{2}{*}{$\begin{array}{c}\text { Contamination } \\
\text { level }\end{array}$} \\
\hline & $\mathrm{Cr}$ & $\mathrm{Ni}$ & $\mathrm{Cu}$ & As & $\mathrm{Cd}$ & $\mathrm{Pb}$ & & \\
\hline $\mathrm{S}_{1}$ & 0.30 & 0.66 & 0.09 & 0.28 & 2.66 & 0.08 & 4.07 & Low \\
\hline $\mathrm{S}_{2}$ & 0.13 & 0.24 & 2.37 & 2.98 & 7.93 & 0.66 & 14.31 & Considerable \\
\hline $\mathrm{S}_{3}$ & 0.21 & 0.71 & 0.16 & 0.24 & 1.21 & 0.32 & 2.85 & Low \\
\hline $\mathrm{S}_{4}$ & 0.24 & 0.49 & 0.81 & 1.39 & 3.21 & 0.68 & 6.82 & Moderate \\
\hline $\mathrm{S}_{5}$ & 0.04 & 0.18 & 0.12 & 0.26 & 0.93 & 0.14 & 1.66 & Low \\
\hline $\mathrm{S}_{6}$ & 0.02 & 0.09 & 0.26 & 0.25 & 3.77 & 0.27 & 4.66 & Low \\
\hline $\mathrm{S}_{7}$ & 0.04 & 0.09 & 0.65 & 0.16 & 0.38 & 0.25 & 1.57 & Low \\
\hline $\mathrm{S}_{8}$ & 0.16 & 0.69 & 0.58 & 0.17 & 1.98 & 0.40 & 3.97 & Low \\
\hline $\mathrm{S}_{9}$ & 0.11 & 0.08 & 0.26 & 0.23 & 0.66 & 0.15 & 1.49 & Low \\
\hline $\mathrm{S}_{10}$ & 0.05 & 0.35 & 0.18 & 0.25 & 0.39 & 0.04 & 1.27 & Low \\
\hline
\end{tabular}

Table 6. Potential ecological risk factor, risk index and pollution degree of heavy metals in soil.

\begin{tabular}{|c|c|c|c|c|c|c|c|c|}
\hline \multirow{2}{*}{ Sites } & \multicolumn{6}{|c|}{ Potential ecological risk factor $\left(\mathrm{E}_{\mathrm{r}}^{\mathrm{i}}\right)$} & \multirow{2}{*}{ Potential Risk (PER) } & \multirow{2}{*}{ Pollution degree } \\
\hline & $\mathrm{Cr}$ & $\mathrm{Ni}$ & $\mathrm{Cu}$ & As & $\mathrm{Cd}$ & $\mathrm{Pb}$ & & \\
\hline $\mathrm{S}_{1}$ & 2.98 & 19.94 & 2.20 & 13.89 & 400.19 & 2.02 & 441.21 & Very high risk \\
\hline $\mathrm{S}_{2}$ & 1.34 & 7.23 & 59.18 & 148.95 & 1189.67 & 16.60 & 1422.97 & Very high risk \\
\hline $\mathrm{S}_{3}$ & 2.09 & 21.30 & 3.89 & 12.23 & 182.26 & 7.91 & 229.68 & Considerable risk \\
\hline $\mathrm{S}_{4}$ & 2.43 & 14.57 & 20.19 & 69.60 & 481.89 & 16.96 & 605.65 & Very high risk \\
\hline $\mathrm{S}_{5}$ & 0.37 & 5.45 & 2.92 & 13.03 & 139.01 & 3.53 & 164.32 & Considerable risk \\
\hline $\mathrm{S}_{6}$ & 0.24 & 2.58 & 6.56 & 12.51 & 564.95 & 6.82 & 593.66 & Very high risk \\
\hline $\mathrm{S}_{7}$ & 0.43 & 2.67 & 16.32 & 8.20 & 56.73 & 6.15 & 90.50 & Moderate risk \\
\hline $\mathrm{S}_{8}$ & 1.56 & 20.59 & 14.56 & 8.35 & 296.44 & 10.04 & 351.53 & Very high risk \\
\hline $\mathrm{S}_{9}$ & 1.13 & 2.31 & 6.56 & 11.32 & 98.94 & 3.73 & 123.99 & Moderate risk \\
\hline $\mathrm{S}_{10}$ & 0.50 & 10.49 & 4.57 & 12.51 & 58.63 & 1.10 & 87.80 & Moderate risk \\
\hline
\end{tabular}

Table 7. Indices and grades of potential ecological risk of heavy metal pollution (Luo et al., 2007).

\begin{tabular}{|c|c|c|c|c|c|c|c|}
\hline Contamination & $\begin{array}{c}\text { Contamination } \\
\text { degree of }\end{array}$ & $\begin{array}{c}\text { Degree of } \\
\text { contamination }\end{array}$ & $\begin{array}{c}\text { Contamination } \\
\text { degree of }\end{array}$ & $\mathrm{E}^{\mathrm{i}}$ & $\begin{array}{c}\text { Grade of } \\
\text { ecological risk } \\
\text { of }\end{array}$ & \multicolumn{2}{|c|}{ Risk index (PER) } \\
\hline$C_{f}^{i}<1$ & Low & $C_{d}<5$ & $\begin{array}{c}\text { Low } \\
\text { contamination }\end{array}$ & $E_{r}^{i}<40$ & Low risk & $\mathrm{RI}<65$ & Low risk \\
\hline $1 \leq C_{f}^{i}<3$ & Moderate & $5 \leq C_{d}<10$ & $\begin{array}{c}\text { Moderate } \\
\text { contamination }\end{array}$ & $40 \leq E_{r}^{i}<80$ & Moderate risk & $65 \leq \mathrm{RI}<130$ & $\begin{array}{l}\text { Moderate } \\
\text { risk }\end{array}$ \\
\hline $3 \leq C_{f}^{i}<6$ & Considerable & $10 \leq C_{d}<20$ & $\begin{array}{l}\text { Considerable } \\
\text { contamination }\end{array}$ & $80 \leq E_{r}^{i}<160$ & $\begin{array}{c}\text { Considerable } \\
\text { risk }\end{array}$ & $130 \leq \mathrm{RI}<260$ & $\begin{array}{c}\text { Considerable } \\
\text { risk }\end{array}$ \\
\hline \multirow[t]{2}{*}{$C_{f}^{i} \geq 6$} & High & $C_{d} \geq 20$ & $\begin{array}{c}\text { High } \\
\text { contamination }\end{array}$ & $160 \leq E_{r}^{i}<320$ & High risk & $\mathrm{RI} \geq 260$ & $\begin{array}{l}\text { Very high } \\
\text { risk }\end{array}$ \\
\hline & & & & $E_{r}^{i} \geq 320$ & Very high risk & & \\
\hline
\end{tabular}



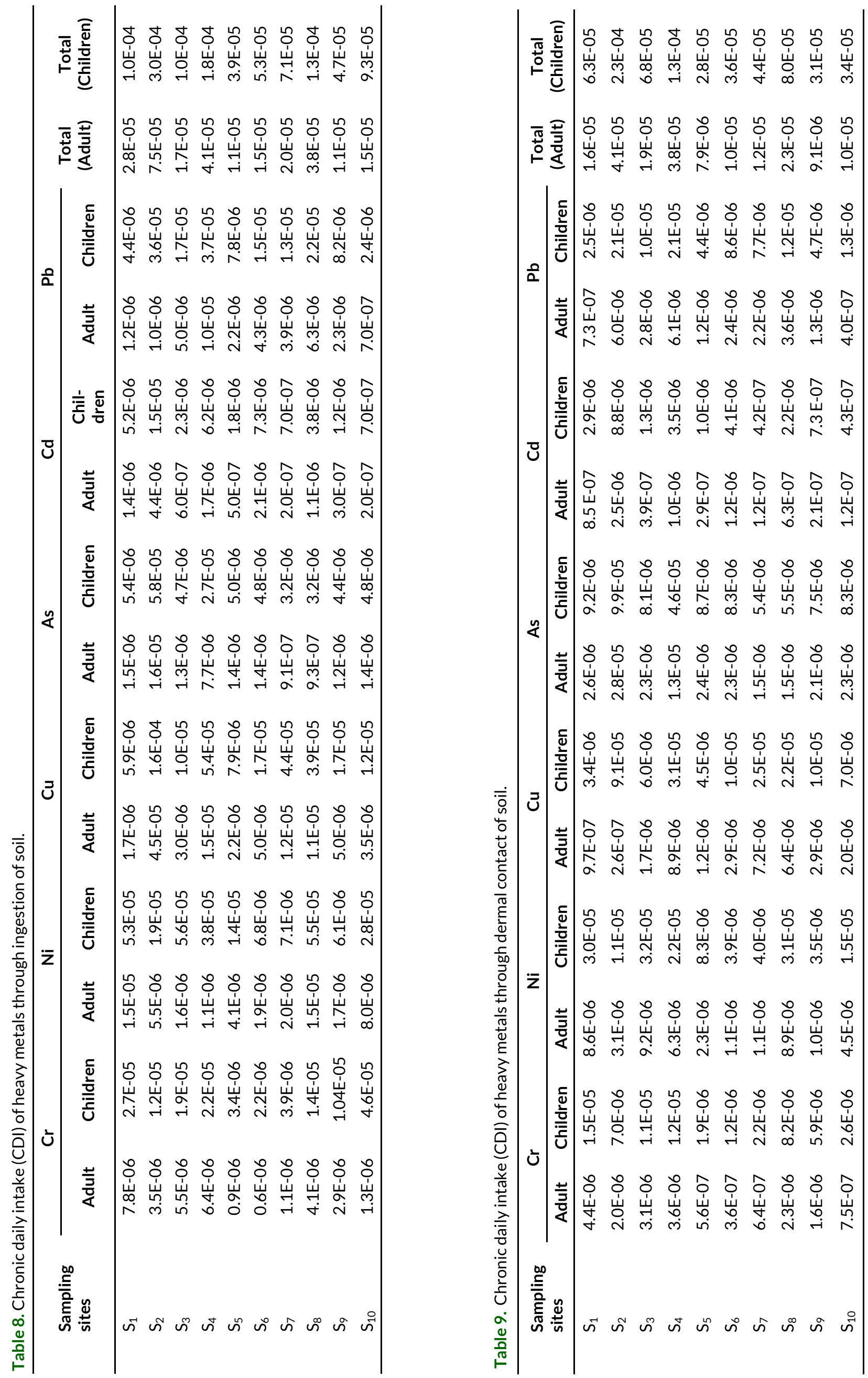

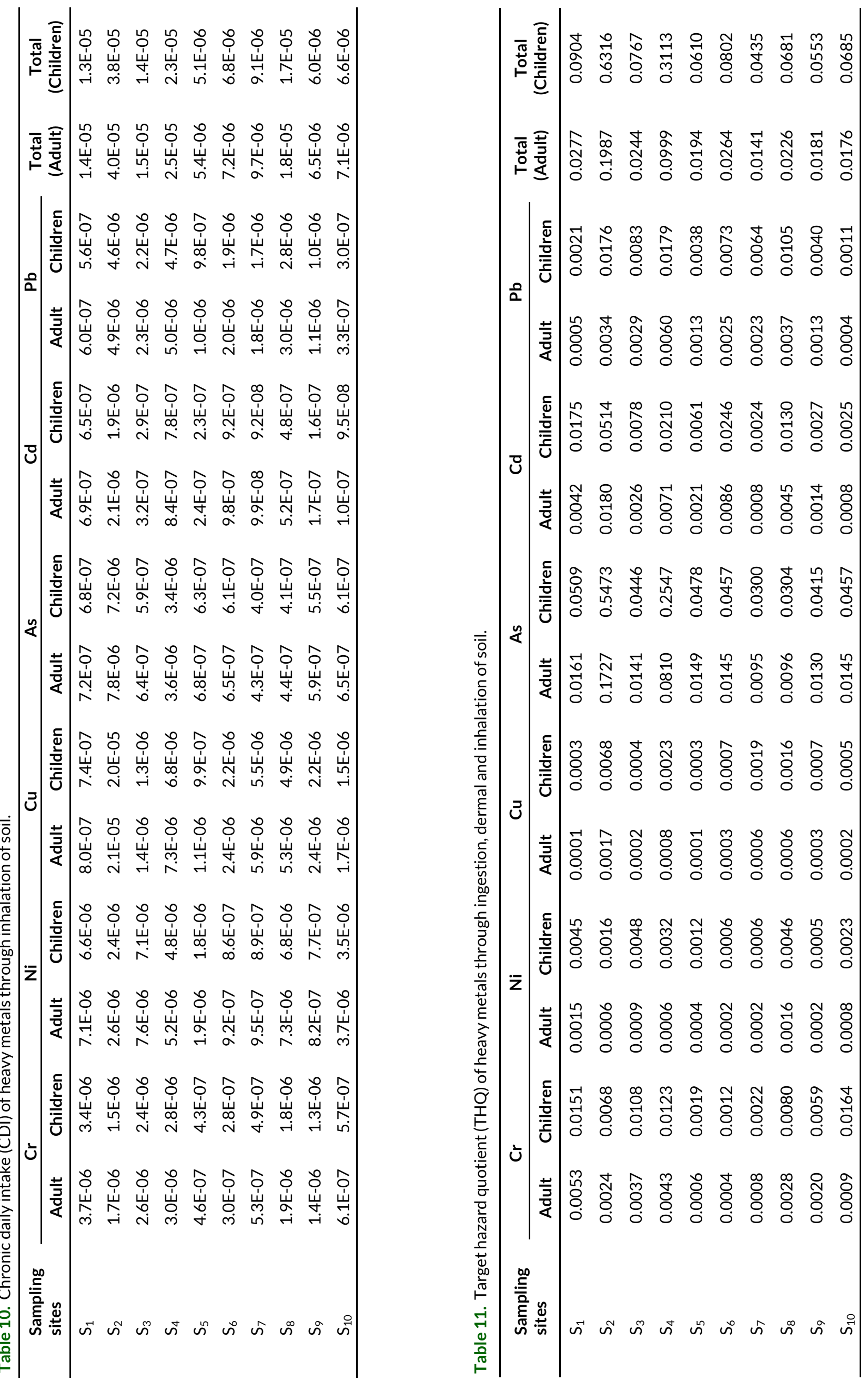
Table 12. Carcinogenic risk of adult due to ingestion, dermal contact and inhalation of arsenic and lead in soil.

\begin{tabular}{|c|c|c|c|c|c|c|c|c|}
\hline \multirow[b]{2}{*}{ Sampling sites } & \multicolumn{4}{|c|}{ Arsenic (As) } & \multicolumn{4}{|c|}{ Lead (Pb) } \\
\hline & Ingestion & $\begin{array}{l}\text { Dermal } \\
\text { contact }\end{array}$ & Inhalation & Total risk & Ingestion & $\begin{array}{l}\text { Dermal } \\
\text { contact }\end{array}$ & Inhalation & Total risk \\
\hline $\mathrm{S}_{1}$ & 3.79E-09 & 8.57E-07 & $3.33 E-13$ & $8.60 \mathrm{E}-07$ & 1.77E-11 & $1.01 \mathrm{E}-08$ & $7.68 \mathrm{E}-14$ & $1.01 \mathrm{E}-08$ \\
\hline $\mathrm{S}_{2}$ & 4.07E-08 & $9.19 \mathrm{E}-06$ & 5.57E-12 & $9.23 \mathrm{E}-06$ & $1.46 \mathrm{E}-10$ & 8.33E-08 & $6.32 \mathrm{E}-13$ & 8.34E-08 \\
\hline $\mathrm{S}_{3}$ & 3.33E-09 & 7.53E-07 & $2.93 \mathrm{E}-13$ & $7.56 \mathrm{E}-07$ & $6.96 \mathrm{E}-11$ & $3.96 \mathrm{E}-08$ & $3.01 \mathrm{E}-13$ & $3.96 \mathrm{E}-08$ \\
\hline $\mathrm{S}_{4}$ & $1.90 \mathrm{E}-08$ & $4.29 \mathrm{E}-06$ & $1.67 \mathrm{E}-12$ & 4.30E-06 & $1.49 \mathrm{E}-10$ & $8.51 \mathrm{E}-08$ & $6.45 \mathrm{E}-13$ & $8.52 \mathrm{E}-08$ \\
\hline $\mathrm{S}_{5}$ & $3.56 \mathrm{E}-09$ & 8.05E-07 & 3.13E-13 & 8.08E-07 & $2.02 \mathrm{E}-11$ & 1.77E-08 & $1.34 \mathrm{E}-13$ & 1.77E-08 \\
\hline $\mathrm{S}_{6}$ & $3.42 \mathrm{E}-09$ & $7.73 \mathrm{E}-07$ & $3.00 \mathrm{E}-13$ & $7.76 \mathrm{E}-07$ & $6.00 \mathrm{E}-11$ & $3.42 \mathrm{E}-08$ & $2.59 \mathrm{E}-13$ & $3.42 \mathrm{E}-08$ \\
\hline $\mathrm{S}_{7}$ & $2.24 \mathrm{E}-09$ & $5.06 \mathrm{E}-07$ & $1.97 \mathrm{E}-13$ & $5.08 \mathrm{E}-07$ & $5.42 \mathrm{E}-11$ & $3.08 \mathrm{E}-08$ & $2.34 \mathrm{E}-13$ & $3.08 \mathrm{E}-08$ \\
\hline $\mathrm{S}_{8}$ & $2.28 \mathrm{E}-09$ & $5.16 \mathrm{E}-07$ & $2.00 \mathrm{E}-13$ & $5.18 \mathrm{E}-07$ & 8.83E-11 & 5.03E-08 & $3.82 \mathrm{E}-13$ & 5.03E-08 \\
\hline $\mathrm{S}_{9}$ & $3.09 \mathrm{E}-09$ & $6.98 \mathrm{E}-07$ & $2.71 \mathrm{E}-13$ & 7.01E-07 & $3.28 \mathrm{E}-11$ & $1.87 \mathrm{E}-08$ & $1.42 \mathrm{E}-13$ & $1.87 \mathrm{E}-08$ \\
\hline$S_{10}$ & $3.42 \mathrm{E}-09$ & $7.73 E-07$ & $3.00 \mathrm{E}-13$ & $7.76 \mathrm{E}-07$ & $9.69 \mathrm{E}-12$ & $1.10 \mathrm{E}-08$ & 4.19E-14 & $1.10 \mathrm{E}-08$ \\
\hline
\end{tabular}

Table 13. Carcinogenic risk of children due to ingestion, dermal contact and inhalation of arsenic and lead in soil.

\begin{tabular}{lcccccccc}
\hline \multirow{2}{*}{$\begin{array}{l}\text { Sampling } \\
\text { sites }\end{array}$} & \multicolumn{9}{c}{ Arsenic (As) } \\
\cline { 2 - 9 } $\mathrm{S}_{1}$ & Ingestion & $\begin{array}{c}\text { Dermal } \\
\text { contact }\end{array}$ & Inhalation & Total risk & Ingestion & $\begin{array}{c}\text { Dermal } \\
\text { contact }\end{array}$ & Inhalation & Total risk \\
\cline { 2 - 9 } $\mathrm{S}_{2}$ & $1.01 \mathrm{E}-08$ & $3.21 \mathrm{E}-08$ & $3.33 \mathrm{E}-13$ & $4.22 \mathrm{E}-08$ & $4.73 \mathrm{E}-11$ & $3.79 \mathrm{E}-10$ & $7.69 \mathrm{E}-14$ & $4.26 \mathrm{E}-10$ \\
$\mathrm{~S}_{3}$ & $1.08 \mathrm{E}-07$ & $3.44 \mathrm{E}-07$ & $3.57 \mathrm{E}-12$ & $4.52 \mathrm{E}-07$ & $3.89 \mathrm{E}-10$ & $3.11 \mathrm{E}-09$ & $6.32 \mathrm{E}-13$ & $3.49 \mathrm{E}-09$ \\
$\mathrm{~S}_{4}$ & $8.86 \mathrm{E}-09$ & $2.82 \mathrm{E}-08$ & $2.93 \mathrm{E}-13$ & $3.70 \mathrm{E}-08$ & $1.85 \mathrm{E}-10$ & $1.48 \mathrm{E}-09$ & $3.01 \mathrm{E}-13$ & $1.66 \mathrm{E}-09$ \\
$\mathrm{~S}_{5}$ & $5.07 \mathrm{E}-08$ & $1.60 \mathrm{E}-07$ & $1.67 \mathrm{E}-12$ & $2.10 \mathrm{E}-07$ & $3.98 \mathrm{E}-10$ & $3.18 \mathrm{E}-09$ & $6.45 \mathrm{E}-13$ & $3.57 \mathrm{E}-09$ \\
$\mathrm{~S}_{6}$ & $9.51 \mathrm{E}-09$ & $3.01 \mathrm{E}-08$ & $3.13 \mathrm{E}-13$ & $3.96 \mathrm{E}-08$ & $8.30 \mathrm{E}-11$ & $6.64 \mathrm{E}-10$ & $1.34 \mathrm{E}-13$ & $7.47 \mathrm{E}-10$ \\
$\mathrm{~S}_{7}$ & $9.12 \mathrm{E}-09$ & $2.89 \mathrm{E}-08$ & $3.00 \mathrm{E}-13$ & $3.80 \mathrm{E}-08$ & $1.60 \mathrm{E}-10$ & $1.28 \mathrm{E}-09$ & $2.59 \mathrm{E}-13$ & $1.44 \mathrm{E}-09$ \\
$\mathrm{~S}_{8}$ & $5.98 \mathrm{E}-09$ & $1.89 \mathrm{E}-08$ & $1.97 \mathrm{E}-13$ & $2.48 \mathrm{E}-08$ & $1.44 \mathrm{E}-10$ & $1.15 \mathrm{E}-09$ & $2.34 \mathrm{E}-13$ & $1.29 \mathrm{E}-09$ \\
$\mathrm{~S}_{9}$ & $6.09 \mathrm{E}-09$ & $1.93 \mathrm{E}-08$ & $2.00 \mathrm{E}-13$ & $2.53 \mathrm{E}-08$ & $2.35 \mathrm{E}-10$ & $1.88 \mathrm{E}-09$ & $3.82 \mathrm{E}-13$ & $2.11 \mathrm{E}-09$ \\
$\mathrm{~S}_{10}$ & $8.24 \mathrm{E}-09$ & $2.61 \mathrm{E}-08$ & $2.71 \mathrm{E}-13$ & $3.43 \mathrm{E}-08$ & $8.75 \mathrm{E}-11$ & $7.00 \mathrm{E}-10$ & $1.42 \mathrm{E}-13$ & $7.87 \mathrm{E}-10$ \\
& $9.12 \mathrm{E}-09$ & $1.44 \mathrm{E}-08$ & $2.75 \mathrm{E}-13$ & $2.35 \mathrm{E}-08$ & $2.58 \mathrm{E}-11$ & $2.09 \mathrm{E}-10$ & $4.19 \mathrm{E}-13$ & $2.35 \mathrm{E}-10$ \\
\hline
\end{tabular}

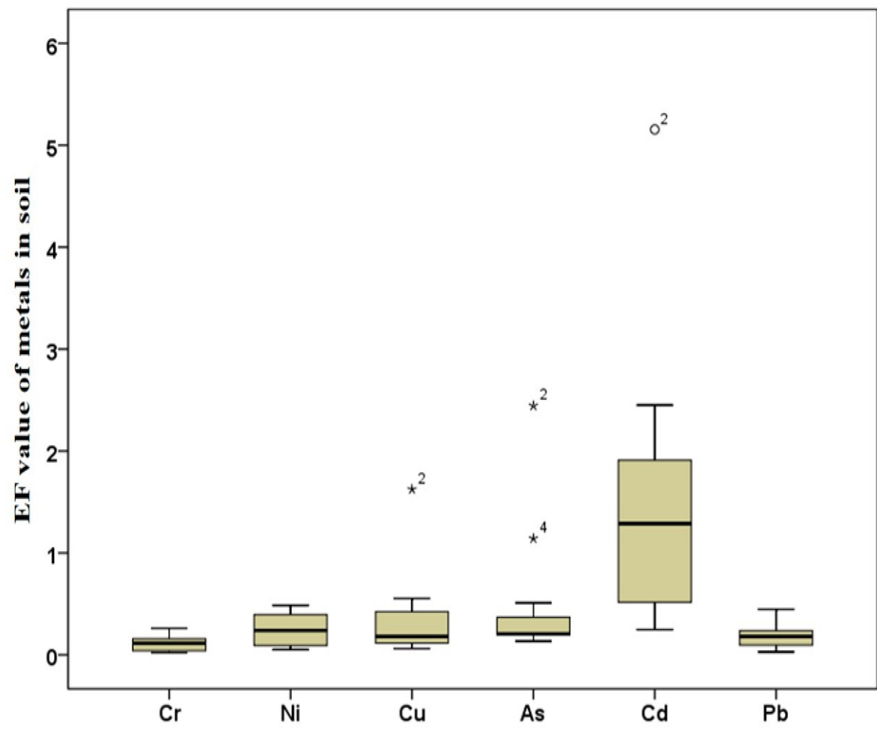

Figure 3. Enrichment factor values of heavy metals in soil.

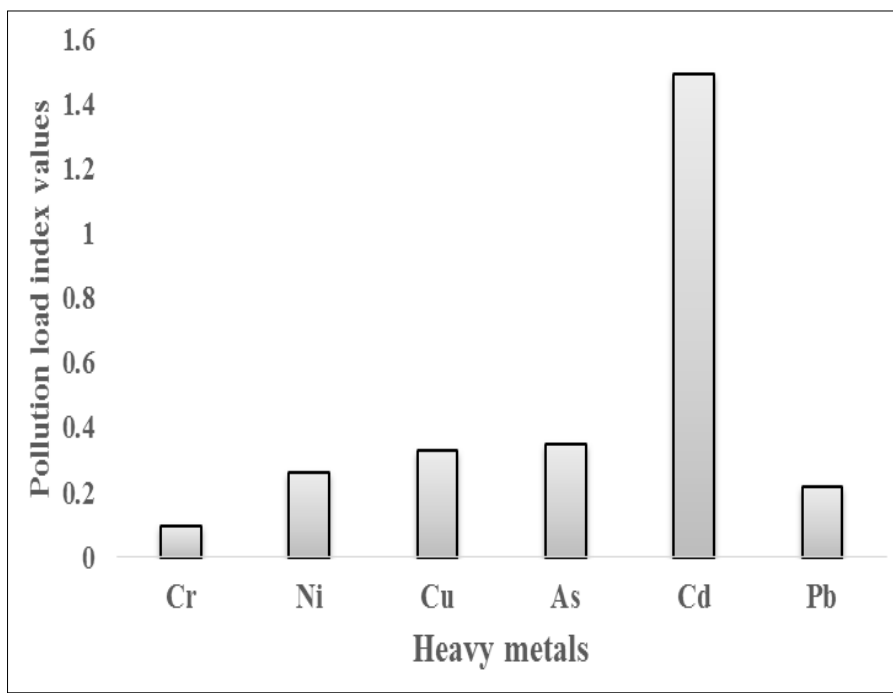

Figure 4. Pollution load index values of heavy metals in soil. 
Toxic unit analysis of the present study was shown in Figure 5. A moderate to serious toxicity of hazardous elements remain in soil when the sum of toxic units for all soil samples is more than 4 (Bai et al., 2011). In the present study, only sampling site 2 exceeds the standard value indicating serious toxicity of hazardous elements in soil.

\section{Health risk assessment}

Heavy metals present in soils may have an impact on human health (Okorie et al., 2011). In the industrial areas, the risks of hazardous elements in industrial, waste burning sites, waste thronging sites and brick fields are important for the exposure through ingestion and dermal contact (Bright et al., 2006; De Miguel et al., 2007; Zheng et al., 2010). According to the risk assessment approach, non-carcinogenic risks of trace metals through two exposure pathways were characterized in this study. In order to evaluate the risk, the chronic daily intakes (CDIs), hazard quotients (HQs), hazard index (HI) and carcinogenic risk of the studied metals were estimated for adults and children and the results are presented hereby.

Chronic daily intake (CDI) of heavy metals through ingestion, dermal contact and inhalation for adult and children was presented in Tables 8, 9 and 10. On the basis of ingestion, the chronic daily intake of total metals ranged from $1.1 \mathrm{E}-05$ to $7.5 \mathrm{E}-$ 05 for adult and 3.90E-05 to 3.00E-04 for children. According to dermal contact, chronic daily intake of total metals ranged from 9.1E-06 to 4.10E-05 for adult and 2.80E-05 to 2.30E-04 for children. Due to inhalation, $\mathrm{CDI}$ of heavy metals ranged from 5.40E-06 to 4.00E-05 for adult and 2.30E-05 to 3.80E-05 for children. Chronic daily intake was higher in children than the adult for ingestion, dermal contact and inhalation as body weight of children was lower than the adult.

The Hazard quotients (HQs) of individual metal for the present study were shown in Table 11. Hazard quotients were calculated from according to ingestion, dermal contact and inhalation concentration of metals. The non-cancer health risks related to individual element exposure through soil ingestion, dermal contact and inhalation was low for all investigated elements resulted in $\mathrm{HQ}<1$, indicating low risk for both adults and children.

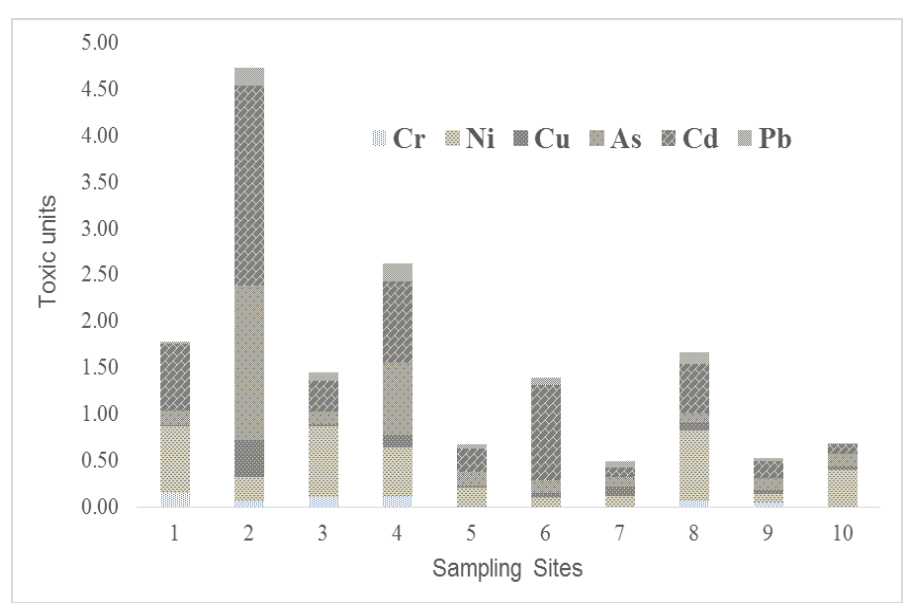

Figure 5. Toxic unit analysis of heavy metals in soil.
The combined effects of exposed metals and metalloids were calculated as hazard index $(\mathrm{HI})$ and the data indicated that the $\mathrm{HI}$ values were also lower than one. However, when considering the total exposure $\mathrm{HI}$ of ingestion, dermal contact and inhalation there was no chance of having non-cancer risk at all of the sites on adults and children health. The total hazard index for children and adult was 0.0176 and 0.0685 , respectively (Figure 6). The hazard risk index values for children were higher than that of adult inhabitants indicating children may pose non-cancer risk in the future. The hazard index value for children was higher in children than adult on the basis of ingestion, dermal contact and inhalation. The total target hazard quotients (THQ) for children was higher due to touching and mouthing of dust contaminated particles, direct ingestion by hand to mouth activities (Mielke et al., 1999). The ingestion of greater amounts of small particles may have greater impact on children because of their small body weight than adult (Beamer et al., 2008). Children are exposed to higher amount of soil than the adult due to pica and play behavior (CDC, 2005).

The carcinogenic risk of $\mathrm{As}$ and $\mathrm{Pb}$ for adults are presented in Table 12 and 13. The carcinogenic risks from $\mathrm{As}$ and $\mathrm{Pb}$ at all sites via ingestion, dermal contact and inhalation were in acceptable ranges. The cancer risk of $\mathrm{As}$ and $\mathrm{Pb}$ ranged from 5.18E -07 to 9.23E-06 and 1.01E-08 to8.34E-08 for adult. The range of carcinogenic risk of children for As was 2.35E-08 to 4.52E-07 and for $\mathrm{Pb}$ was 2.35E-10 to 3.57E-09. For all sampling sites, carcinogenic risk posed by $\mathrm{As}$ and $\mathrm{Pb}$ was lower than $10^{-6}$ through different exposure pathways. The carcinogenic risks of As and $\mathrm{Pb}$ due to exposure from studied soil via ingestion, dermal contact and inhalation pathways can be negligible in the industrial areas of Tangail district, Bangladesh, as Cancer risk value for all sites were lower than target value $10^{-6}$ (USEPA, 2011). Among the three exposure pathways, the ingestion of soil seems to be the major pathway of exposure to hazardous elements followed by dermal contact and inhalation. Hazardous elements could be accumulated in human for a long time and especially non-cancer adverse effects of these toxic metals to the tissues of adult population can become more serious. According to the result of present study, health risk for adult and children due to heavy metal exposure through soil could not be overlooked.

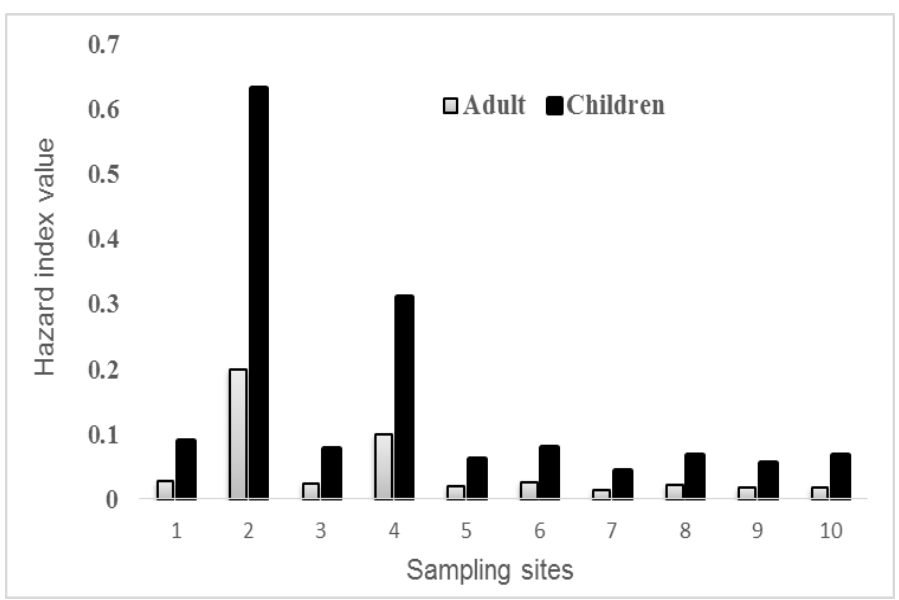

Figure 6. Hazard index (HI) of heavy metals due to ingestion, dermal contact and inhalation of soil. 
Conclusion

The major findings of the study revealed that $\mathrm{Cd}$ concentrations in some sampling sites exceeded the Dutch standard and Canadian quality guidelines values, representing that the studied soils were heavily polluted by $\mathrm{Cd}$. The enrichment factor, geoaccumulation index, contamination factor, pollution load index and toxic unit analysis values were found low for all metals except $\mathrm{Cd}$. Toxic elements in different sampling sites showed moderate to very high degree of contamination. The severity of potential ecological risk factor for single metal $\left(E_{r}^{i}\right)$, only $\mathrm{Cd}$ had very severe ecological risk for most of the sampling sites in the study area. Ingestion and dermal contact of the toxic elements in adult and children body in the study area have no probability to pose the non-cancer risk. But the concern is that long term exposure of these toxic elements can pose cancer both in child and adult population around the industrial vicinity of Tangail district in Bangladesh.

\section{ACKNOWLEDGEMENTS}

The authors thank the authority of Patuakhali Science and Technology University (PSTU), Bangladesh, and Yokohama National University, Japan, for providing laboratory facilities to complete this study.

\section{Conflict of interest}

No any conflict of interest is declared by the authors.

Open Access: This is an open access article distributed under the terms of the Creative Commons Attribution 4.0 License, which permits unrestricted use, distribution, and reproduction in any medium, provided the original author(s) if the sources are credited.

\section{REFERENCES}

Acosta, J.A., Faz, A., Martínez-Martínez, S., Zornoza, R., Carmona, D.M. and Kabas, S. (2011). Multivariate statistical and GIS-based approach to evaluate heavy metals behavior in mine sites for future reclamation. Journal of Geochemical Exploration, 109: 8-17, https://doi.org/10.1016/ j.gexplo.2011.01.004

Adeniyi, A.A., Yusuf, K.O. and Okedeyi, O.O. (2008). Assessment of the exposure of two fish species to metals pollution in the Ogun river catchments, Kettu, Lagos, Nigeria. Environmental Monitoring and Assessment, 137: 451-458, https://doi.org/10.1007/s10661-007-9780-5

Ahmad, S., Siddiqui, E.N. and Khalid, S. (1996). Studies on certain physico chemical properties of soil of two fresh water ponds of Darbhanga. Environmental Pollution, 31: 31-39.

Alam, M.G.M., Snow, E.T. and Tanaka, A. (2003). Arsenic and heavy metal contamination of vegetables grown in Samta village, Bangladesh. Science of the Total Environment, 308: 83 -96, https://doi.org/10.1016/S0048-9697(02)00651-4
Alloway, B.J. (1990). Heavy metals in soils. John Wiley and Sons, Inc. New York. ISBN 0470215984.

Amuno, S.A. (2013). Potential ecological risk of heavy metal distribution in cemetery soils. Water Air and Soil Pollution, 224: 1435-1446.

Arenas-Lago, D., Vega, F.A., Silva, L.F.O. and Andrade, M.L. (2014). Copper distribution in surface and subsurface soil horizons. Environmental Science and Pollution Research, 21: 1099711008, https://doi.org/10.1007/s11356-014-3084-4

Arenas-Lago, D., Vega, F.A., Silva, L.F.O. and Andrade, M.L. (2013). Soil interaction and fractionation of added cadmium in some Galician soils. Microchemical Journal, 110: 681-690, https://doi.org/10.1016/j.microc.2013.08.003

Asaduzzaman, A.T.M., Nury, S.N., Hoque, S. and Sultana, S. (2002). Water and soil contamination from tannery waste: Potential impact on public health in Hazaribag and surroundings, Dhaka, Bangladesh. Atlas of Urban Geology, 14: 415-443.

ATSDR (Agency for Toxic Substances and Disease Registry). (2007). Toxicological profile for Lead. U.S. Department of Health and Human Services, Atlanta, Georgia 30333. Accessed on January 20, 2018 from https:// www.atsdr.cdc.gov/tox profiles/tp13.pdf

ATSDR (Agency for Toxic Substances and Disease Registry). (2008). Agency for Toxic Substances and Disease Registry. Division of Toxicology and Environmental Medicine/ Applied Toxicology Branch, MN, Retrieved on March 10 2012 from https://www.atsdr.cdc.gov/toxprofiles/tp.asp? id $=102 \&$ tid $=23 \mathrm{~S}$

ATSDR (Agency for Toxic Substances and Disease Registry). (2012). Toxicological profile for Chromium. U.S. Department of Health and Human Services, Atlanta, Georgia 30333. Accessed on January 10, 2018 from https://www.atsdr.cdc.gov/toxprofiles/tp7.pdf

Bai, J., Xiao, R., Cui, B., Zhang, K., Wang, Q., Liu, X., Gao, H. and Huang, L. (2011). Assessment of heavy metal pollution in wetland soils from the young and old reclaimed regions in the Pearl River Estuary, South China. Environmental Pollution, 159: 817-824, https://doi.org/10.1016/ j.envpol.2010.11.004

Baralkiewicz, D. and Siepak, J. (1999). Chromium, Nickel and Cobalt in Environmental Samples and Existing Legal Norms. Polish Journal of Environmental Studies, 8: 201-208.

BBS, (2011). Bangladesh Population and Housing Census (BBS): National Report, Volume - 4

Beamer, P., Key, M.E., Ferguson, A.C., Canales, R.A., Auyeung, W. and Leckie, J.O. (2008). Quantified activity pattern data from 6 to 27 month-old farm worker children for use in exposure assessment. Environmental Research, 108: 239246, https://doi.org/10.1016/j.envres.2008.07.007

Bhagure, G.R. and Mirgane, S. R. (2011). Heavy metal concentrations in groundwaters and soils of Thane Region of Maharashtra, India. Environmental Monitoring and Assessment, 173: 643652, https://doi.org/10.1007/s10661-010-1412-9 
Bhuiyan, M.A.H., Parvez, L., Islam, M., Dampare, S.B. and Suzuki, S. (2010). Heavy metal pollution of coal mine-affected agricultural soils in the northern part of Bangladesh. Journal of Hazardous Materials, 173: 384-392, https:// doi.org/10.1016/j.jhazmat.2009.08.085

Bhuiyan, M.A.H., Suruvi, N.I., Dampare, S.B., Islam, M.A., Quraishi, S.B., Ganyaglo, S. and Suzuki, S. (2011). Investigation of the possible sources of heavy metal contamination in lagoon and canal water in the tannery industrial area in Dhaka, Bangladesh. Environmental Monitoring and Assessment, 175: 633-649, https://doi.org/10.1007/s10661-010-1557-6

Bhuyan, M.S. and Bakar, M.A. (2017). Seasonal variation of heavy metals in water and sediments in the Halda River, Chittagong, Bangladesh. Environmental Science and Pollution Research, 35: 27587-27600, https://doi.org/ 10.1007/s11356-017-0204-y

Bhuyan, M.S. and Islam, M.S. (2017). A Critical Review of Heavy Metal Pollution and Its Effects in Bangladesh. Science Journal of Energy Engineering, 5: 95-108, https:// doi.org/10.11648/j.sjee.20170504.13

Bhuyan, M.S., Bakar, M.A., Akhtar, A., Hossain, M.B., Ali, M.M. and Islam, M.S. (2017). Heavy Metal Contamination in Surface Water and Sediment of the Meghna River, Bangladesh. Environmental Nanotechnology, Monitoring \& Management, 8: 273-279, https://dx.doi.org/10.1016/ j.enmm.2017.10.003

Birch, G.F. and Olmos, M.A. (2008). Sediment-bound heavy metals as indicators of human influence and biological risk in coastal water bodies. ICES Journal of Marine Science, 65: 1407-1413, https://doi.org/10.1093/icesjms/fsn139

Branca, M., Dessi, A., Kozlowski, H., Micera, G. and Swiatek, J. (1990). Reduction of chromate ions by glutatione tripeptide in the presence of sugar ligands. Journal of Inorganic Biochemistry, 39: 217-226.

CCME, Canadian Council of Ministers of the Environment (2003). Canadian Environmental Quality Guidelines.

CDC, Centers for Disease Control and Prevention (2005). Preventing lead poisoning in young children, Atlanta.

Chen, T.B., Zheng, Y.M. and Chen, H. (2005). Arsenic accumulation in soils for different land use types in Beijing. Geography Resources, 24: 229-235.

Chen, X., Xia, X.H., Zhao, Y. and Zhang, P. (2010). Heavy metal concentrations in roadside soils and correlation with urban traffic in Beijing, China. Journal of Hazardous Materials, 181: 640-646, https://doi.org/10.1016/j.jhazmat.2010.05.060

DEP (Department of Environmental Protection). (2003). Assessment Levels for Soil, Sediment and Water Contaminated Sites Management Series Perth's, Australia. www.environ.wa.gov.au/.

Dojlido, J.R. and Best, G.A. (1993). Chemistry of Water and Water Pollution, Ellis Horwood Limited, New York.

Franco-Uria, A., Lopez-Mateo, C., Roca, E. and FernandezMarcos, M.L. (2009). Source identification of heavy metals in pastureland by multivariate analysis in NW Spain.
Journal of Hazardous Materials, 165: 1008-1015, https://doi.org/10.1016/j.jhazmat.2008.10.118

Frank, R., Ishida, K. and Suda, P. (1976). Metals in agricultural soils of Ontario. Canadian Journal of Soil Science, 56: I8I-196.

Fryer, M., Collins, C.D., Ferrier, H., Colvile, R.N. and Nieuwenhuijsen, M.J. (2006). Human exposure modeling for chemical risk assessment: a review of current approaches and research and policy implications. Environmental Science \& Policy, 9: 261-274, https://doi.org/10.1016/ j.envsci.2005.11.011

Guney, M., Zagury, G.J., Dogan, N. and Onay, T.T. (2010). Exposure assessment and risk characterization from trace elements following soil ingestion by children exposed to playgrounds, parks and picnic areas. Journal of Hazardous Materials, 182: 656-664, https://doi.org/10.1016/ j.jhazmat.2010.06.082

Guo, W., Liu, X., Liu, Z. and Li, G. (2010). Pollution and potential ecological risk evaluation of heavy metals in the sediments around Dongjiang Harbor, Tianjin. Procedia Environmental Sciences, 2: 729-736, https://doi.org/10.1016/ j.proenv.2010.10.084

Håkanson, L. (1980). An ecological risk index for aquatic pollution control: a sedimentological approach. Water Research, 14: 975-1001.

Hasnine, M.T., Huda, M.E., Khatun, R., Saadat, A.H.M., Ahasan, M., Akter, S., Uddin, M.F., Monika, A.N., Rahman, M.A. and Ohiduzzaman, M. (2017). Heavy Metal Contamination in Agricultural Soil at DEPZA, Bangladesh. Environment and Ecology Research, 5: 510-516, https://doi.org/10.13189/ eer.2017.050707.

Hu, X., Zhang, Y., Ding, Z.., Wang, T., Lian, H., Sun, Y. and Wu, J. (2012). Bioaccessibility and health risk of arsenic and heavy metals (Cd, Co, Cr, Cu, Ni, Pb, Zn and Mn) in TSP and PM2. 5 in Nanjing, China. Atmospheric Environment, 57: 146-152, https://doi.org/10.1016/j.atmosenv.2012.04.056

Hug, S.J., Gaertner, D., Roberts, L.C., Schirmer, M., Ruettimann, T., Rosenberg, T.M., Badruzzaman, A.T.M. and Ali, M.A. (2011). Avoiding high concentrations of arsenic, manganese and salinity in deep tubewells in Munshiganj District, Bangladesh. Applied Geochemistry, 26: 1077-1085.

Huq, S.I. and Shoaib, J.M. (2013). The soils of Bangladesh, Springer publication. Berlin, Germany.

Islam, M.S., Ahmed, M.K. and Al-Mamun, M.H. (2015b). Metal speciation in soil and health risk due to vegetables consumption in Bangladesh. Environmental Monitoring and Assessment, 187: 288-303, https://doi.org/10.1007/s10661015-4533-3

Islam, M.S., Ahmed, M.K. and Al-Mamun, M.H. (2016). Human exposure of hazardous elements from different urban soils in Bangladesh. Advances in Environmental Research, 5: 79-94, https://doi.org/ 10.12989/aer.2016.5.2.079

Islam, M.S., Ahmed, M.K., Al-Mamun, M.H. and Eaton, D.W. (2017). Human and Ecological Risks of Metals in Soils under Different Land Use in an Urban Environment of 
Bangladesh. Pedosphere, 27: 60395-3, https:// doi.org/10.1016/S1002-0160(17)60395-3

Islam, M.S., Ahmed, M.K., Al-Mamun, M.H. and Hoque, M.F. (2015c). Preliminary assessment of heavy metal contamination in surface sediments from a river in Bangladesh. Environmental Earth Science, 73:1837-1848, https:// doi.org/10.1007/s12665-014-3538-5

Islam, M.S., Ahmed, M.K., Al-Mamun, M.H. and Masunaga, S. (2014). Trace metals in soil and vegetables and associated health risk assessment. Environmental Monitoring and Assessment, 186: 8727-8739, https://doi.org/10.1007/ s10661-014-4040-y

Islam, M.S., Ahmed, M.K., Al-mamun, M.H. and Masunaga, S. (2015a). Potential ecological risk of hazardous elements in different land-use urban soils of Bangladesh. Science of the Total Environment, 512: 94-102, https:// dx.doi.org/10.1016/j.scitotenv.2014.12.100

Islam, M.S., Kormoker, T., Ali, M.M. and Proshad, R. (2018c). Ecological risk analysis of heavy metals toxicity from agricultural soils in the industrial areas of Tangail District, Bangladesh. SF Journal of Environmental and Earth Science, 1: 1022.

Jintao, L., Chen, C., Song, X., Han, Y. and Liang, Z. (2011). Assessment of heavy metal pollution in soil and plants from Dunhua sewage irrigation area. International Journal of Electrochemical Science, 6: 5314-5324.

Karim, R.A., Hossain, S.M., Miah, M.M.H., Nehar, K. and Mubin, M.S.H. (2008). Arsenic and heavy metal concentrations in surface soils and vegetables of Feni District in Bangladesh. Environmental Monitoring and Assessment, 145: 417-425, https://doi.org/10.1007/s10661-007-0050-3

Karim, Z., Qureshi, B.A., Mumtaz, M. and Qureshi, S. (2014). Heavy metal content in urban soils as an indicator of anthropogenic and natural influences on landscape of Karachi-a multivariate spatio-temporal analysis. Ecological Indicators, 42: 20-31, https://doi.org/10.1016/ j.ecolind.2013.07.020

Kashem, M.A. and Singh, B.R. (1999). Heavy metal contamination of soil and vegetation in the vicinity of industries in Bangladesh. Water Air and Soil Pollution, 115: 347-361.

Khan, S., Cao, Q., Zheng, Y.M., Huang, Y.Z. and Zhu, Y.G. (2008). Health risks of heavy metals in contaminated soils and food crops irrigated with wastewater in Beijing, China. Environmental Pollution, 152: 686-692, https:// doi.org/10.1016/j.envpol.2007.06.056

Khan, S., Rehman, S., Khan, A.Z., Khan M. A. and Shah, M.T. (2010). Soil and vegetables enrichment with heavy metals from geological sources in Gilgit, Northern Pakistan. Ecotoxicology and Environmental Safety, 73: 1820-1827, https://doi.org/10.1016/j.ecoenv.2010.08.016

Krishna, A.K. and Govil, P.K. (2007). Soil contamination due to heavy metals from an industrial area of Surat, Gujarat, Western India. Environmental Monitoring and Assessment, 124: 263-275, https://doi.org/10.1007/s10661006-9224-7
Lee, P.K., Youm, S.J. and Jo, H.Y. (2013). Heavy metal concentrations and contamination levels from Asian dust and identification of sources: a case-study. Chemosphere, 91: 10181025, https://doi.org/10.1016/j.chemosphere.2013.01.074

Li, H.B., Yu, S., Li, G.L., Deng, H. and Luo, X.S. (2011). Contamination and source differentiation of $\mathrm{Pb}$ in park soils along an urban-rural gradient in Shanghai. Environmental Pollution, 159: 3536-3544, https://doi.org/10.1016/ j.envpol.2011.08.013

$\mathrm{Li}$, J. (2014). Risk assessment of heavy metals in surface sediments from the Yanghe River, China. International Journal of Environmental Research and Public Health, 11: 12441-53, https://doi.org/10.3390/ijerph111212441

Luo, W., L.u, Y., Gisey, J.P., Wang, T., Shi, Y. and Wang, Y. (2007). Effects of land use on concentrations of metals in surface soils and ecological risk around Guanting Reservoir, China. Environmental Geochemistry and Health, 29: 459-471, https://doi.org/10.1007/s10653-007-9115-z

Luo, X.S., Yu, S. and Li, X.D. (2011). Distribution, availability, and sources of trace metals in different particle size fractions of urban soils in Hong Kong: implications for assessing the risk to human health. Environmental Pollution, 159: 1317-1326, https://doi.org/10.1016/j.envpol.2011.01.013

Man, Y.B., Sun, X.L., Zhao, Y.G., Lopez, B.N., Chung, S.S., Wu, S.C. and Cheung, K.C. (2010). Health risk assessment of abandoned agricultural soils based on heavy metal contents in Hong Kong, the world's most populated city. Environment International, 36: 570-576, https://doi.org/10.1016/ j.envint.2010.04.014

Martley, E., Gulson, B.L. and Pfeifer, H.R. (2004). Metal concentrations in soils around the copper smelter and surrounding industrial complex of Port Kembla, NSW, Australia. Science of the Total Environment, 325: 113-127, https:// doi.org/10.1016/j.scitotenv.2003.11.012

Mass, S., Scheifler, R., Benslama, M., Crini, N., Lucot, E. and Brahmia, Z. (2011). Heavy metal concentrations in soil and wild plants growing around $\mathrm{Pb}-\mathrm{Zn}$ sulfide terrain in the Kohistan region, northern Pakistan. Microchemical Journal, 99: 67-75, https://doi.org/10.1016/j.microc.2011.03.012

Mclaughlin, M.J., Parker, D.R. and Clarke, J.M. (1999). Metals and micronutrients-food safety issues. Field Crop Research, 60: 143-163.

Mielke, H.W., Gonzales, C.R., Smith, M.K. and Mielke, P.W. (1999). The urban environment and children's health: soils as an integrator of lead, zinc, and cadmium in New Orleans, Louisiana, USA. Environmental Research, 81: 117-129.

Needleman, H.L. (1980). Low Level Lead Exposure: the Clinical Implications of Current Research. New York: Raven Press.

NEPA (National Environmental Protection Agency of China). (1995). Environmental Quality Standard for Soils (GB 15618-1995). Beijing: China Environmental Science Press.

Neumann, R.B., Ashfaque, K., Badruzzaman, A.B.M., Ali, M.A. and Shoemaker, J. (2010). Anthropogenic influences on groundwater arsenic concentrations in Bangladesh. Nature Geoscience, 3: 46-52. 
Neumann, R.B., St Vincent, A.P., Roberts, L.C., Badruzzaman, A.B.M., Ali, M.A. and Harvey, C.F. (2011). Rice field geochemistry and hydrology: an explanation for why groundwater irrigated fields in Bangladesh are net sinks of arsenic from groundwater. Environmental Science \& Technology, 45: 2072-2078, https://doi.org/10.1021/ es102635d

Nriagu, J.O. (1988). A silent epidemic of environmental metal poisoning? Environmental Pollution, 50: 139-161.

Nziguheba, G. and Smolders, E. (2008). Inputs of trace elements in agricultural soils via phosphate fertilizers in European countries. Science of the Total Environment, 390: 53-57, https://doi.org/10.1016/j.scitotenv.2007.09.031

Okorie, A., Entwistle, J. and Dean, J.R. (2011). The application of in vitro gastrointestinal extraction to assess oral bioaccessibility of potentially toxic elements from an urban recreational site. Applied Geochemistry, 26: 789-796, https://doi.org/10.1016/j.apgeochem.2011.01.036

Olawoyin, R., Oyewole, S.A. and Grayson, R.L. (2012). Potential risk effect from elevated levels of soil heavy metals on human health in the Niger delta. Ecotoxicology and Environmental Safety, 85: 120-130, https://doi.org/10.1016/ j.ecoenv.2012.08.004

Oliveira, M.L.S., Ward, C.R., Izquierdo, M., Sampaio, C.H., de Brum, I.A., Kautzmann, R.M., Sabedot, S., Querol, X. and Silva, L.F. (2012). Chemical composition and minerals in pyrite ash of an abandoned sulphuric acid production plant. Science of the Total Environment, 430: 34-47, https:// doi.org/10.1016/j.scitotenv.2012.04.046

Oliver, M.A. (1997). Soil and human health: a review. European Journal of Soil Science, 48: 573-592.

Ordóñez, A., Álvarez, R., Charlesworth, S.De., Miguel, E. and Loredo, J. (2011). Risk assessment of soils contaminated by mercury mining, Northern Spain. Journal of Environmental Monitoring, 13: 128-136, https://doi.org/10.1039/ COEM00132E

Panda, S.K. (2007). Chromium-mediated oxidative stress and ultrastructural changes in root cells of developing rice seedlings. Journal of Plant Physiology, 164: 1419-1428, https://doi.org/10.1016/j.jplph.2007.01.012

Panda, S.K. and Patra, H.K. (2000). Nitrate and ammonium ions effect on the chromium toxicity in developing wheat seedlings. Proceedings of the National Academy of Sciences India. Section B, Biological Sciences, 70: 75-80.

Polizzotto, M.L., Lineberger, E.M., Matteson, A.R., Neumann, R.B. and Badruzzaman, A.B.M. and Ali, M. (2013). Arsenic transport in irrigation water across rice-field soils in Bangladesh. Environmental Pollution, 179: 210-217, https:// doi.org/10.1016/j.envpol.2013.04.025

Proshad, R., Ahmed, S., Rahman, M. and Kumar, T. (2017a). Apportionment of Hazardous Elements in Agricultural Soils Around the Vicinity of Brick Kiln in Bangladesh. Journal of Environmental and Analytical Toxicology, 7: 439, https:// doi.org/ 10.4172/2161-0525.1000439
Proshad, R., Islam, M.S. and Kormoker, T. (2018b). Assessment of heavy metals with ecological risk of soils in the industrial vicinity of Tangail district, Bangladesh. International Journal of Advanced Geosciences, 6: 108-116, https://doi.org/ 10.14419/ijag.v6i1.9791

Proshad, R., Kormoker, T., Mursheed, N., Islam, M.M., Bhuyan, M.I., Islam, M.S. and Mithu, T.N. (2018a). Heavy metal toxicity in agricultural soil due to rapid industrialization in Bangladesh: a review. International Journal of Advanced Geosciences, 6: 83-88, https://doi.org/10.14419/ijag.v6i1.9174

Proshad, R., Rahman, M.M., Kumar, T., Islam, M.S., Mursheed, N. and Howladar, R. (2017b). Human health hazard implications of heavy metals in agricultural foodstuff grown around brick kiln areas in Bangladesh. Journal of Environmental Science, Computer Science and Engineering \& Technology, 6: 138-156, https:// doi.org/10.24214/jecet.A.6.2.13856

Qu, C.S., Sun, K., Wang, S.R., Huang, L. and Bi, J. (2012). Monte Carlo simulation based health risk assessment of heavy metal pollution: a case study in Qixia mining area, China. Human and Ecological Risk Assessment- An International Journal, 18: 733-750, https:// doi.org/10.1080/10807039.2012.688697

Rachwał, M., Kardel, K., Magiera, T. and Bens, O. (2017). Application of magnetic susceptibility in assessment of heavy metal contamination of Saxonian soil (Germany) caused by industrial dust deposition. Geoderma, 295: 1021, https://doi.org/10.1016/j.geoderma.2017.02.007

Rashed, M.N. (2010). Monitoring of contaminated toxic and heavy metals, from mine tailings through age accumulation, in soil and some wild plants at Southeast Egypt, Journal of Hazardous Materials, 178: 739-746, https:// doi.org/10.1016/j.jhazmat.2010.01.147

Rawlins, B.G., Lark, R.M., Webster, R. and O'Donnell, K.E. (2006). The use of soil survey data to determine the magnitude and extent of historic metal deposition related to atmospheric smelter emissions across Humberside, UK. Environmental Pollution, 143: 416-426, https://doi.org/10.1016/ j.envpol.2005.12.010

Renner, R. (2004). Arsenic and lead leach out of popular fertilizer. Environmental Science and Technology, 38: 382A.

Rodríguez Martín, J. A., Ramos-Miras, J.J., Boluda, R. and Gil, C. (2013). Spatial relations of heavy metals in arable and greenhouse soils of a Mediterranean environment region (Spain). Geoderma, 200-201: 180-188.

Rodríguez Martín, J., Gutiérrez, C., Escuer, M., García- González, M.T., Campos-Herrera, R. nad Aguila, N. (2014). Effect of mine tailing on the spatial variability of soil nematodes from lead pollution in La Union (Spain). Science of the Total Environment, 473: 518-529, https://doi.org/10.1016j.scitotenv.2013.12.075

Selvaraj, K., Mohan, V.R. and Szefer, P. (2004). Evaluation of metal contamination in coastal sediments of the Bay of Bengal, India: geo-chemical and statistical approaches. Marine Pollution Bulletin, 49: 174-185, https:// doi.org/10.1016/j.marpolbul.2004.02.006 
Shaker, A.K., Djanaguiraman, M. and Venkateswarlu, B. (2009). Chromium in plants: current status and future strategies. Metallomics, 1: 375-383.

Siciliano, S.D., James, K., Zhang, G.Y., Schafer, A.N. and Peak, J.D. (2009). Adhesion and enrichment of metals on human hands from contaminated soil at an Arctic urban brownfield. Environmental Science and Technology, 43: 6385-6390, https://doi.org/10.1021/es901090w

Soil Survey Division Staff. (1993). Soil survey manual. Soil conservation service. U.S. Department of Agriculture handbook 18.

Sonmez, S., Kaplan, M., Sonmez, N.K., Kaya, H. and Uz, I. (2006). High level of copper application to soil and leaves reduce the growth and yield of tomato plants. Scientia Agricola, 63: 213-218, http://dx.doi.org/10.1590/S010390162006000300001

SRDI (2009). Saline Soils of Bangladesh by Soil Resources Development Institute, Dhaka, Bangladesh.

Srinivasa, G.S., Reddy, M.R. and Govil, P.K. (2010). Assessment of heavy metal contamination in soils at Jajmau (Kanpur) and Unnao industrial areas of the Ganga Plain, Uttar Pradesh, India. Journal of Hazardous Materials, 174: 113121, https://doi.org/10.1016/j.jhazmat.2009.09.024

Sun, Y.B., Zhou, Q.X., Xie, X.K. and Liu, R. (2010). Spatial, sources and risk assessment of heavy metal contamination of urban soils in typical regions of Shenyang, China. Journal of Hazardous Materials, 174: 455-462, https:// doi.org/10.1016/j.jhazmat.2009.09.074

Suresh, G., Ramasamy, V., Meenakshisundaram, V., Venkatachalapathy, R. and Ponnusamy, V. (2011). Influence of mineralogical and heavy metal composition on natural radionuclide contents in the river sediments. Applied Radiation and Isotopes, 69: 1466-1474, https://doi.org/10.1016/ j.apradiso.2011.05.020

Tokalıglu, S. and Kartal, S. (2006). Multivariate analysis of the data and speciation of heavy metals in street dust samples from the Organized Industrial District in Kayseri (Turkey). Atmospheric Environment, 40: 2797-2805, https:// doi.org/10.1016/j.atmosenv.2006.01.019

Turekian, K.K. and Wedepohl, K.H. (1961). Distribution of the elements in some major units of the earth's crust. Geological Society of America Bulletin, 72: 175-192.

USDOE. (2011). The Risk Assessment Information System (RAIS). U.S. Department of Energy's Oak Ridge Operations Office (ORO).

USDOE. (2011). The Risk Assessment Information System (RAIS). U.S. Department of Energy's Oak Ridge Operations Office (ORO).

USEPA. (1986). Guidelines for the Health Risk Assessment of Chemical Mixtures. 51 Federal Register 34014, Washington, D.C.

USEPA. (1989). Risk Assessment Guidance for Superfund, Vol. I: Human Health Evaluation Manual. EPA/540/1-89/002. Office of Solid Waste and Emergency Response, Washington, D.C.

USEPA. (1989). Risk assessment guidance for superfund. Human Health Eval Manual (part A). vol. I; EPA/540/1-89/002.
USEPA. (1997). Exposure factors handbook. EPA/600/P95/002F. Washington, DC. Environmental Protection Agency, Office of Research and Development.

USEPA. (1999). Screening Level Ecological Risks Assessment Protocol for Hazardous Waste Combustion Facilities. Appendix E: Toxicity Reference Values.

USEPA. (2001). Supplemental Guidance for Developing Soil Screening Levels for Superfund Sites. OSWER 9355.4-24. Office of Solid Waste and Emergency Response, Washington, D.C.

USEPA. (2001). Supplemental guidance for developing soil screening levels for superfund sites. Washington, DC: Office of Solid Waste and Emergency Response.

USEPA. (2002). Supplemental Guidance for Developing Soil Screening Levels for Superfund Sites. U.S. Environmental Protection Agency, pp. 4-24 (OSWER 9355).

USEPA. (2010). Risk-based Concentration Table Available from: http://www.epa.gov/reg3hwmd/risk/human/index.htm.

USEPA. (2011). Exposure factors handbook: 2011 Edition. National Center for Environmental Assessment, Office of Research and Development, Washington, DC 20460, EPA/ 600/R-09/052F.

USPHS. (1997). Toxicological profile on CD-ROM. Agency for Toxic Substances and Disease Registry.

VROM. (2000). Ministry of Housing, Spatial Planning and Environment. Circular on Target Values and Intervention Values for Soil Remediation. Ministry of Housing, Netherlands.

White, P.J. and Brown, P.H. (2010). Plant nutrition for sustainable development and global health. Annals of Botany, 105: 1073-1080, https://doi.org/10.1093/aob/mcq085

Wu, Y., Xu, Y., Zhang, J. and Hu, S. (2010). Evaluation of ecological risk and primary empirical research on heavy metals in polluted soil over Xiaoqinling gold mining region, Shaanxi, China. Trans. Transactions of Nonferrous Metals Society of China, 20: 688-694.

Yap, D.W., Adezrian, J., Khairiah, J., Ismail, B.S. and Ahmad-Mahir, R. (2009). The uptake of heavy metals by paddy plants (Oryza sativa) in Kota Marudu, Sabah, Malaysia. American-Eurasian Journal of Agricultural \& Environmental Science, 6: 16-19.

Yu, L., Xin, G., Gang, W., Qiang, Z., Qiong, S. and Guoju, X. (2008). Heavy metal contamination and source in arid agricultural soil in central Gansu Province, China. Journal of Environmental Sciences, 20: 607-612.

Yuan, G.L., Liu, C., Chen, L. and Yang, Z. (2011). Inputting history of heavy metals into the inland lake recorded in sediment profiles: Poyang Lake in China. Journal of Hazardous Materials, 185: 336-345, https://doi.org/10.1016/ j.jhazmat.2010.09.039

Zhang, J. and Liu, C.L. (2002). Riverine composition and estuarine geochemistry of particulate metals in Chinaweathering features, anthropogenic impact and chemical fluxes. Estuarine, Coastal and Shelf Sciences, 54: 1051-1070, https://doi.org/10.1006/ecss.2001.0879

Zhao, Q., Wang, Y., Cao, Y., Chen, A., Ren, M., Ge, Y., Yu, Z., Wan, S., Hu, A., Bo, Q., Ruan, L., Chen, H., Qin, S., Chen, W., Hu, C., 
Tao, F., Xu, D., Xu, J., Wen, L. and Li. L. (2014). Potential health risks of heavy metals in cultivated topsoil and grain, including correlations with human primary liver, lung and gastric cancer, in Anhui province, Eastern China. Science of the Total Environment, 470-471: 340-347, https://doi.org/10.1016/j.scitotenv.2013.09.086
Zheng, N., Wang, Q., Liang, Z. and Zheng, D. (2008). Characterization of heavy metal concentrations in the sediments of three freshwater rivers in Huludao City, Northeast China. Environmental Pollution, 154: 135-142, https://doi.org/10.1016/ j.envpol.2008.01.001 